\title{
30. CENOZOIC PLANKTONIC FORAMINIFERS OF THE FALKLAND PLATEAU AND ARGENTINE BASIN, DEEP SEA DRILLING PROJECT LEG 711
}

\author{
Valery A. Krasheninnikov, Geological Institute of the U.S.S.R. Academy of Sciences, Moscow, U.S.S.R. \\ and \\ Ivan A. Basov, Institute of the Lithosphere of the U.S.S.R. Academy of Sciences, Moscow, U.S.S.R.
}

\begin{abstract}
Sites 511 and 512 (Falkland Plateau) and 513 (Argentine Basin) penetrated calcareous-siliceous oozes of the middle and upper Eocene and lower Oligocene with rather numerous planktonic foraminifers. Upper Oligocene, Miocene, Pliocene, and Quaternary sections are composed mostly of siliceous sediments (Sites 511-514) where planktonic foraminifers are rare or absent. High-latitude planktonic foraminifers of the Austral Province are characterized by impoverished assemblages-only representatives of Globigerina, Globigerinita, Globorotaloides, and Globorotalia with a rounded peripheral margin are found. In the Paleogene, these species are supplemented, in lesser amounts, by representatives of Globigerapsis, Acarinina, Pseudogloboquadrina, Pseudohastigerina, and Chiloguembelina. Assemblages of planktonic foraminifers have low stratigraphic resolution, especially in the upper Oligocene-Quaternary. This reflects the generally deteriorating Cenozoic climate, which evinced a sharp change in the upper Oligocene that is connected with initiation of the circum-Antarctic current near the Paleogene/Neogene boundary. Comparison of Paleogene and Neogene planktonic foraminifers of the South Atlantic (Falkland Plateau, Argentine Basin, $46-51^{\circ} \mathrm{S}$ ) and the North Atlantic (Rockall Plateau, $55-56^{\circ} \mathrm{N}$ ) indicates that the South Atlantic climate was much colder than that of the same latitudes of the North Atlantic.

Paleogene oozes of the Falkland Plateau rest unconformably on Maestrichtian sediments and in their turn are overlain unconformably by Neogene-Quaternary oozes. Cenozoic sections are stratigraphically discontinuous: periods of intensive biogenic sedimentation resulting in a thick succession of sediments alternated with periods of nondeposition and strong erosion that resulted in hiatuses and unconformities. In the Argentine Basin, Oligocene calcareous-siliceous oozes rest on basalts of the oceanic basement; they are replaced upward in the section by Neogene-Quaternary siliceous oozes with some hiatuses. Planktonic foraminifers here clearly demonstrate the processes of oceanic subsidence and CCD fluctuations as well as Polar Front migrations during Cenozoic time. Fifty species of planktonic foraminifers are discussed and illustrated.
\end{abstract}

\section{INTRODUCTION}

High-latitude Cenozoic planktonic foraminifers of the Southern Hemisphere are not well studied compared to those from tropical and subtropical regions. This realm is occupied primarily by the waters of the Southern Ocean. On continents and islands, the marine Paleogene and Neogene are developed only within limited areas.

In southern South America, the Cenozoic is represented by continental facies or shallow-water deposits with benthic foraminifers. Only a few authors have mentioned planktonic microfauna. Danian limestones and clays of the Río Negro Province (Argentina) contain Globigerina triloculinoides, G. daubjergensis, and Globorotalia pseudobulloides (Bertels, 1964). The Agua Fresca shale of Magallanes Province, southernmost Chile, is characterized by numerous Globigerina patagonica and belongs to the Eocene (Todd and Kniker, 1952).

Paleogene and Neogene deposits of New Zealand (especially the South Island, $41-46^{\circ} \mathrm{S}$ ) have yielded the most comprehensive information about temperate and cold-water planktonic microfauna. The whole succession of assemblages of planktonic foraminifers, from

\footnotetext{
${ }^{1}$ Ludwig, W. J., Krasheninnikov, V. A., et al., Init. Repts. DSDP, 71: Washington, D.C. (U.S. Govt. Printing Office).
}

the Danian up to the Quaternary, has been traced in South Island land sections (e.g., Hornibrook, 1958, 1961, 1966, 1967, 1968; Jenkins, 1964, 1965a, b, c, 1966, 1970, 1971; Kennett, 1967, 1968). New Zealand planktonic assemblages are marked by many provincial features (low species diversity, presence of some endemics) which result in distinct differences between high- and low-latitude planktonic foraminiferal fauna. These differences make it difficult to apply directly the reliable zonal biostratigraphic schemes worked out by Bolli (1957a, b, c, 1959) and Blow (1969) for correlation and subdivision of Cenozoic deposits in low-latitude regions. Local zonal scales have been created for the Cenozoic of New Zealand. At first, they were not very detailed (Hornibrook, 1958; Geiger, 1962). The zonal scheme of Jenkins $(1966,1967,1971)$ has much higher stratigraphic resolution, but its reliability should be checked in other areas of the high-latitude belt.

Oceanic drilling has recovered sections very important for the Cenozoic stratigraphy of the cold-water areas of the Southern Hemisphere (Legs 28, 29, 35, 36). Sediments with planktonic foraminifers have been penetrated in some holes. In the Indian Ocean, such sediments belong to the upper Eocene, Oligocene, Miocene, and Pliocene (Sites 265, 267, 268, and 269) (Kaneps, 1975; Kennett, 1975). In the Pacific Ocean deposits with planktonic foraminifers are Danian, Oligocene, and Miocene in age (Sites 270, 323, and 325); very complete Paleo- 
gene and Neogene sequences were discovered on the Campbell Plateau, Macquarie Ridge, South Tasman Rise, and the southern part of the Tasman Sea (Sites 277, 278, and 280-284) (Rögl, 1976; Kennett and Vella, 1975; Jenkins, 1975). In the South Atlantic, drilling at Sites 327 and 329 (Falkland Plateau) penetrated calcareous-siliceous oozes of the upper Paleocene, lower Eocene, Oligocene, and lower, middle, and upper Miocene that contained planktonic foraminifers (Tjalsma, 1977).

Leg 71 continued these investigations in the Southern Ocean, in pursuit of regional and general scientific goals of Cenozoic stratigraphic studies: (1) establishment of a regional scheme for subdivision and correlation of $\mathrm{Ce}$ nozoic sediments of the Falkland Plateau and Argentine Basin; (2) correlation of planktonic foraminiferal stratigraphy with biostratigraphic schemes based on various siliceous planktonic microfossils which are widely used in high-latitude stratigraphic investigations; (3) correlation of the regional foraminiferal stratigraphic scheme with the high-latitude foraminiferal zonal scale of New Zealand and the tropical scales of Bolli and Blow. Such a correlation may be possible using data from intermediate, subtropical or temperate areas where one can expect tropical-subtropical foraminiferal and austral species to co-occur; (4) reconstruction of the Cenozoic history of sediment accumulation and of paleoceanological and paleogeographical events of the South Atlantic.

Four sites were drilled during Leg 71, two of them on the Falkland Plateau (Maurice Ewing Bank, Sites 511 and 512) and two in the Argentine Basin (Sites 513 and 514). Planktonic foraminifers are common and relatively rich in systematic composition in the middle and upper Eocene calcareous-siliceous sediments of Sites 511 and 512; they are less diverse and common to few in the Oligocene deposits of Sites 511 and 513, and very impoverished, few to rare or absent in the Neogene-Quaternary siliceous oozes of all sites.

The drilling program could not be completed as planned because of severe weather and sea conditions, and not all scientific goals were reached. Nevertheless, data on the character and distribution of planktonic foraminifers in the Cenozoic sediments obtained during Leg 71, supplemented by Leg 36 materials, make a further contribution to our knowledge of the Cenozoic stratigraphy of the Austral Province.

\section{REGIONAL STRATIGRAPHY}

Figure 1 shows the geographic location of Sites 511514; Figure 2 correlates the Cenozoic sections.

\section{Site 511}

This site is situated at the western margin of the Maurice Ewing Bank ( $51^{\circ} 00.28^{\prime} \mathrm{S}, 46^{\circ} 58.30^{\prime} \mathrm{W}$, in a water depth of $2589 \mathrm{~m}$ ). The Cenozoic sequence was continuously cored with an average recovery of $35 \%$. The Cenozoic sediments recovered in Site 511 are represented by Paleocene-Eocene pelagic clays and upper Eocene, Oligocene, and Pliocene-Quaternary biogenic oozes with a total thickness of 195.0 meters.

\section{Paleocene-Eocene}

Greenish gray pelagic clays barren of foraminifers and tentatively dated by diatoms and radiolarians as Paleocene-Eocene were drilled at the base of the $\mathrm{Ce}$ nozoic section in the interval from 185.5-195.0 meters (Cores 21-22) with a $3.5 \%$ recovery. These sediments overlie unconformably Upper Cretaceous (Maestrichtian) nanno-foraminiferal oozes.

\section{Upper Eocene}

Upper Eocene nannofossil diatomaceous oozes, 38 meters thick, were recovered in the interval from Sample 511-17-1, 90-92 cm to Sample 511-20,CC. They are separated from the underlying, almost barren pelagic clays by a gap and an unconformity, but it is difficult to estimate the duration of this hiatus.

Assemblages of planktonic foraminifers are not very diverse, amounting to 14 species in total. The most common are Globigerina angiporoides angiporoides, G. aff. linaperta, Globorotaloides suteri, and Chiloguembelina cubensis. Globigerapsis index and $G$. aff. tropicalis appear sporadically. These species are accompanied, in the lower part of the upper Eocene section, by rare to few Globigerina tripartita and Globigerinita pera and (in the upper part) by few G. martini, Globorotalia munda, $G$. gemma, Globigerina galavisi, G. praebulloides, and $G$. labiacrassata (Fig. 3).

The planktonic foraminiferal assemblage dates the sediments as late Eocene. The presence of Globigerapsis excludes an Oligocene age; the absence of Acarinina and Pseudogloboquadrina precludes a middle Eocene age. The nannofossil diatomaceous oozes under consideration should be correlated with the G. semiinvoluta, Globorotalia cocoaensis, and $G$. cunialensis zones of the tropical zonal scale; evidently they correspond to part of this stratigraphic interval (most probably, the upper part). The upper Eocene section of the Falkland Plateau can be correlated also with the Globigerina linaperta Zone and the lower part of the G. brevis Zone of New Zealand.

The Eocene/Oligocene boundary is placed just above Sample 511-17-1, 90-92 cm, the last one containing a single specimen of Globigerapsis index. The conventional position of this boundary is obvious. It is possible, however, that very rare specimens of Globigerapsis could be redeposited and the boundary should be placed a little lower. Alternatively, for ecological reasons Globigerapsis may have been excluded from this area before its evolutionary extinction. In this case the boundary should be drawn slightly higher in the section. But this "interval of uncertainty" is very narrow, because overlying sediments contain definite Oligocene microfossils.

\section{Oligocene}

Oligocene sediments, 144.5 meters thick and composed of diatomaceous oozes with subordinate intercalations of nannofossil diatomaceous oozes, were recovered in the interval from Sample 511-1-3, 120-123 cm to Sample $511-16, C C$. The sediments are characterized by 


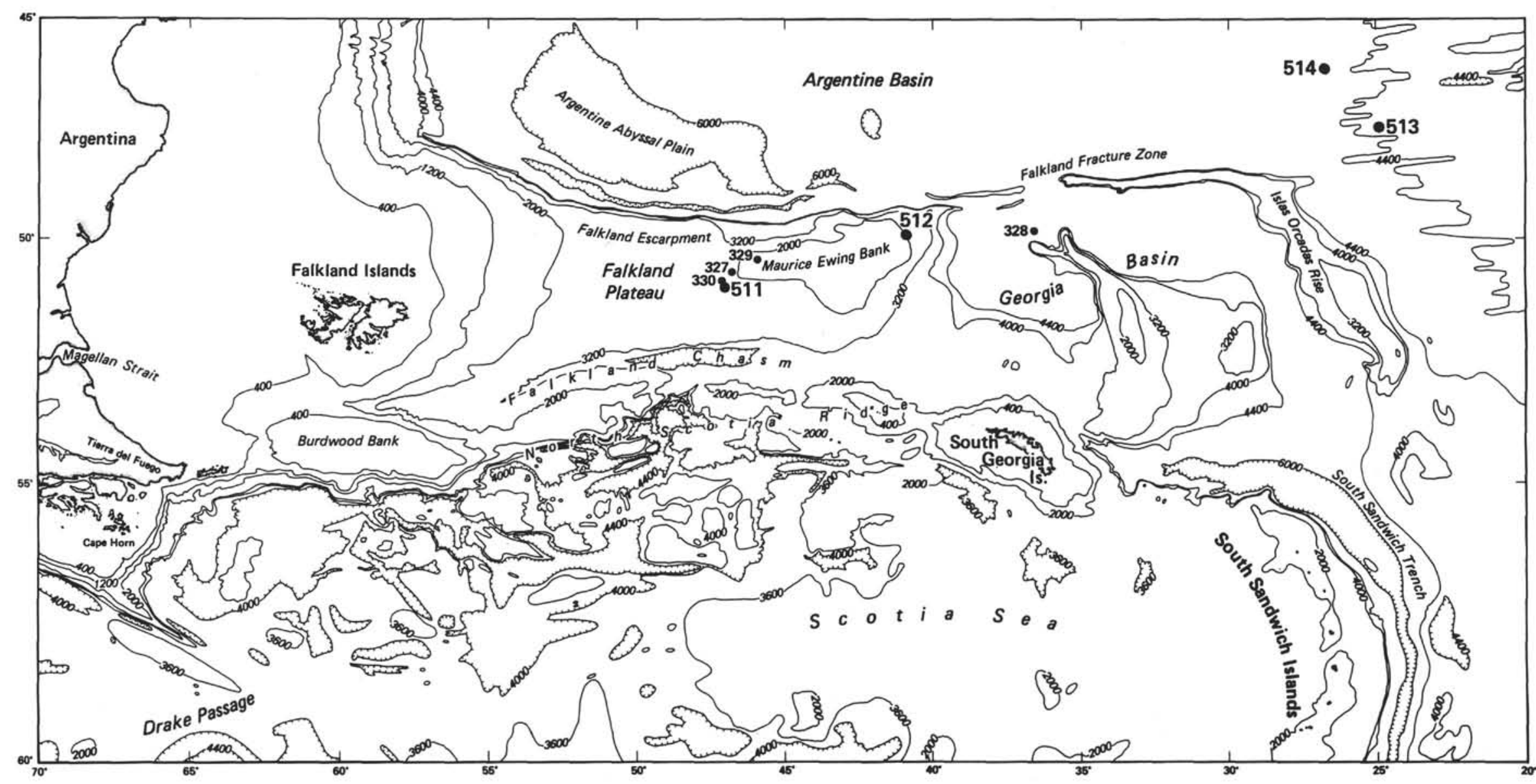

Figure 1. The location of Leg 71 and Leg 36 sites. 


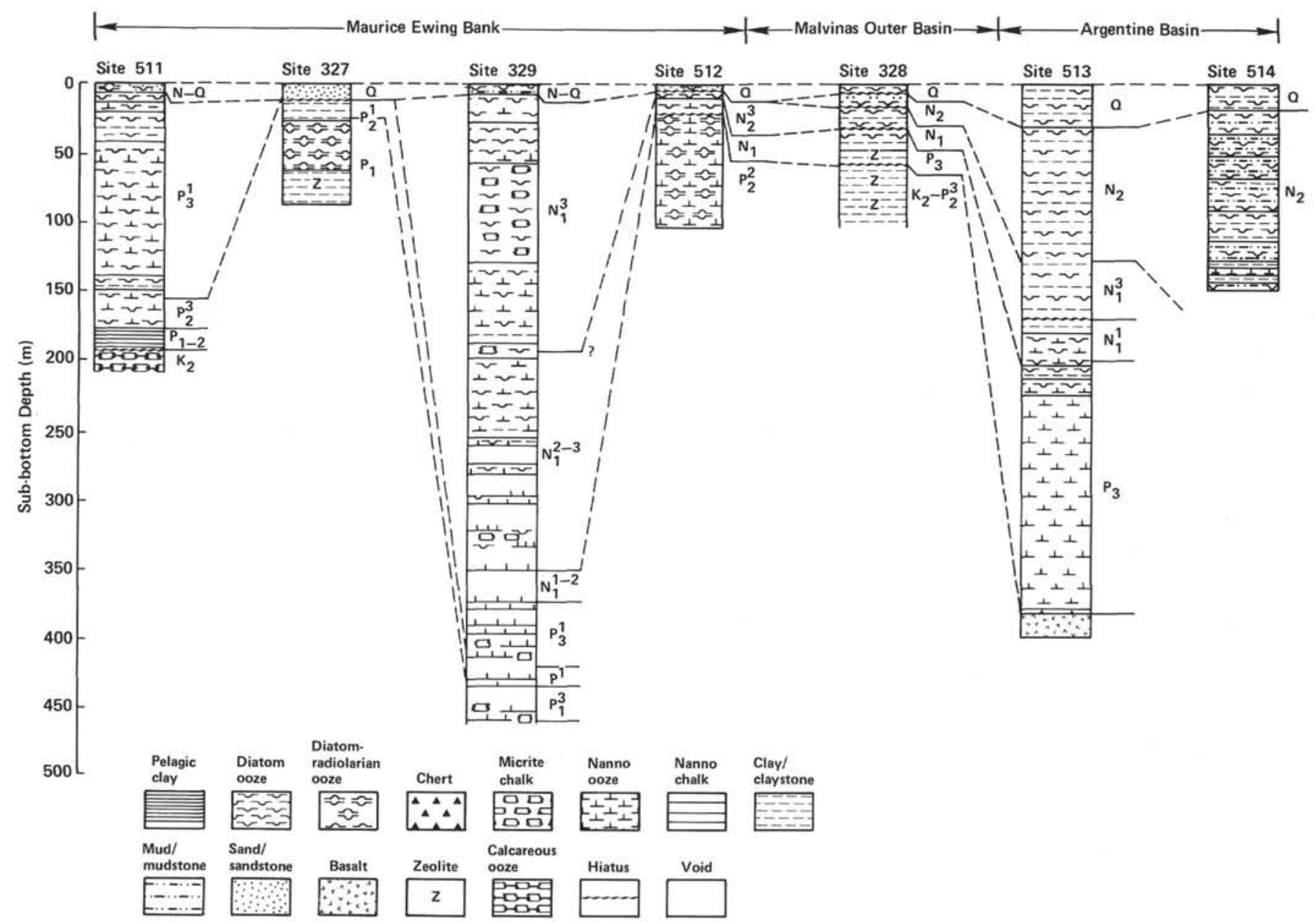

Figure 2. Correlation of Cenozoic sediments in Leg 71 and Leg 36 sites.Q, Quaternary; N, Neogene, (1, 2, or 3); O, Oligocene; P, Paleogene (1, 2, or 3); K, Cretaceous (2).

planktonic foraminiferal assemblages amounting to 16 species; as in the upper Eocene, species diversity is rather low. The quantitative distribution of planktonic foraminifers changes upward in the section, generally tending to decrease toward the top. In Cores $12-16$ foraminifers are rare to few; in Cores 9-11 they are few to common, and taxonomic diversity reaches $\sim 12$ species per sample; in Cores 3-8 they are rare and less diverse; and in Cores 1-2 they are absent.

The assemblage of planktonic foraminifers consists mainly of Globigerina angiporoides angiporoides, $G$. aff. linaperta, G. officinalis, G. ouachitaensis, Globorotaloides suteri, Globorotalia munda, and Chiloguembelina cubensis. Other species, such as Globigerina praebulloides, G. senilis, Globigerinita martini, G. unicava, and Globorotalia gemma are very rare but are constantly present throughout most of the Oligocene section. Globigerina angustiumbilicata and $G$. prasaepis are found in separate samples, mainly in the middle part of the section. This assemblage enables us to attribute the deposits without doubt to the lower Oligocene and to correlate them with the $G$. tapuriensis, the $G$. sellii and the G. ampliapertura zones of Blow's zonal scale (1969). The species composition of this planktonic assemblage resembles the lower Oligocene foraminiferal fauna of the southern part of New Zealand, corresponding to the
G. angiporoides Zone and the upper part of the G. brevis Zone in accordance with the New Zealand scale (Jenkins, 1971).

\section{Pliocene-Quaternary}

The undifferentiated Pliocene-Quaternary diatomaceous oozes recovered in the interval from Sample 511-1, top, to Sample $511-1-2,85-87 \mathrm{~cm}$ are separated by a large hiatus from the lower Oligocene sediments. The assemblage of planktonic foraminifers contains abundant Globigerina bulloides, G. pachyderma, Globorotalia inflata, and G. truncatulinoides, rare to few Globorotalia scitula and Globigerinita uvula, and very rare Globigerinita glutinata. Globorotalia truncatulinoides is represented by low-conical specimens that are considered cool-water forms (subspecies) (Herb, 1968). All of these taxa are at present widely distributed in the high latitudes of the World Ocean.

\section{Site 512}

The site is located at the eastern margin of the Maurice Ewing Bank $\left(49^{\circ} 52.194^{\prime} \mathrm{S}, 40^{\circ} 50.713^{\prime} \mathrm{W}\right.$, in a water depth of $1846 \mathrm{~m})$. It was continuously hydraulic piston cored down to 77.9 meters (Hole 512), and then rotary cored to 87.3 meters (Hole 512A). This site was chosen in order to reconstruct the history of calcareous accum- 


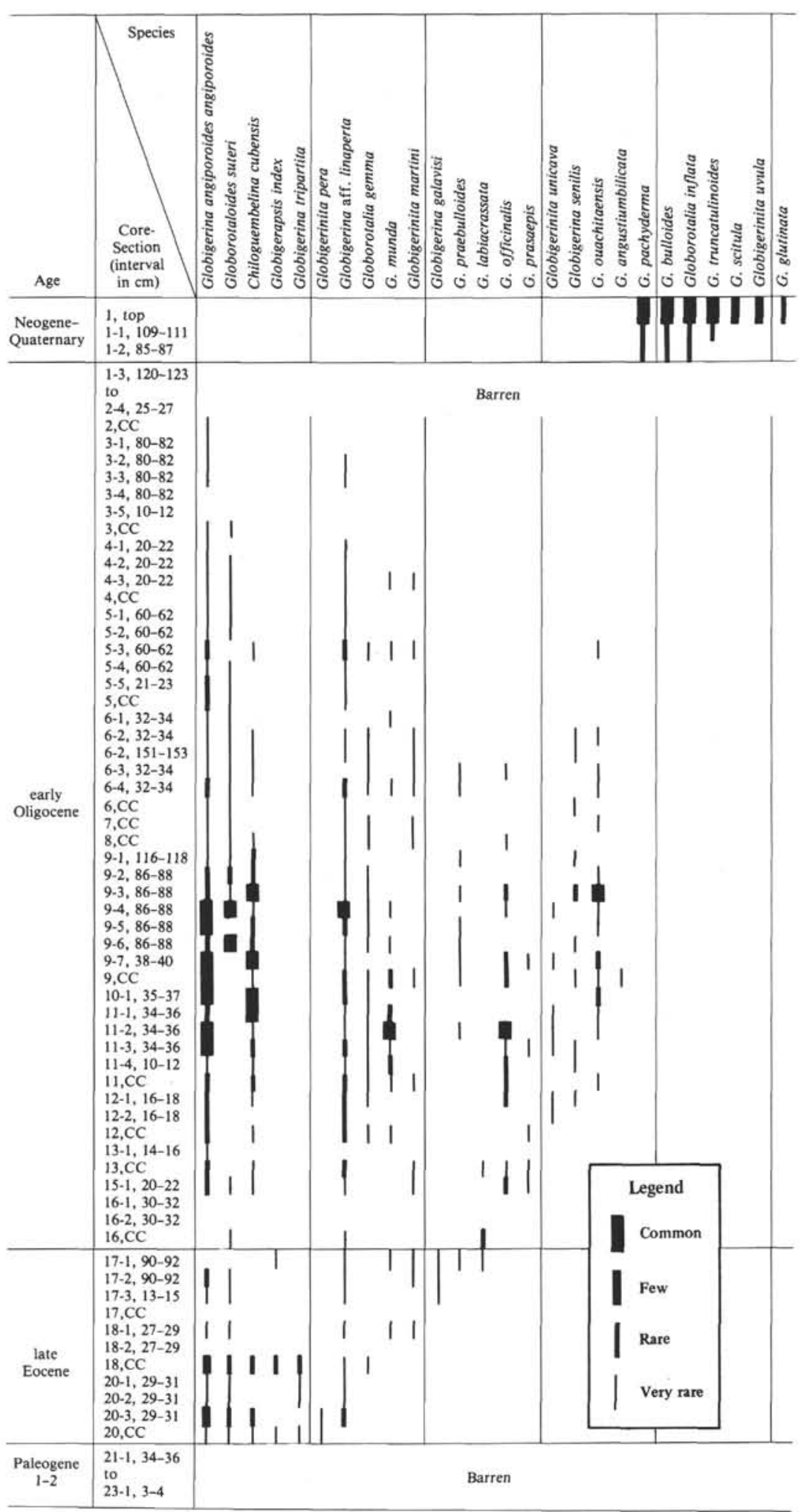

Figure 3. Distribution of planktonic foraminifers in the Cenozoic sediments of Site 511.

ulation and oceanic circulation in the South Atlantic. The position of the site near the top of the Maurice Ewing Bank suggested the possibility of obtaining a complete, relatively shallow water calcareous Cenozoic sequence and evidence of the paleoceanological and erosional events that occurred during the early stages in the formation of the Circumpolar Current. The inception of this current resulted in an irreversible deterioration of the climate in the Southern Hemisphere.

Middle Eocene, middle and upper Miocene, and Quaternary sediments were distinguished at Site 512. All subdivisions contain planktonic foraminifers (Fig. 4). 


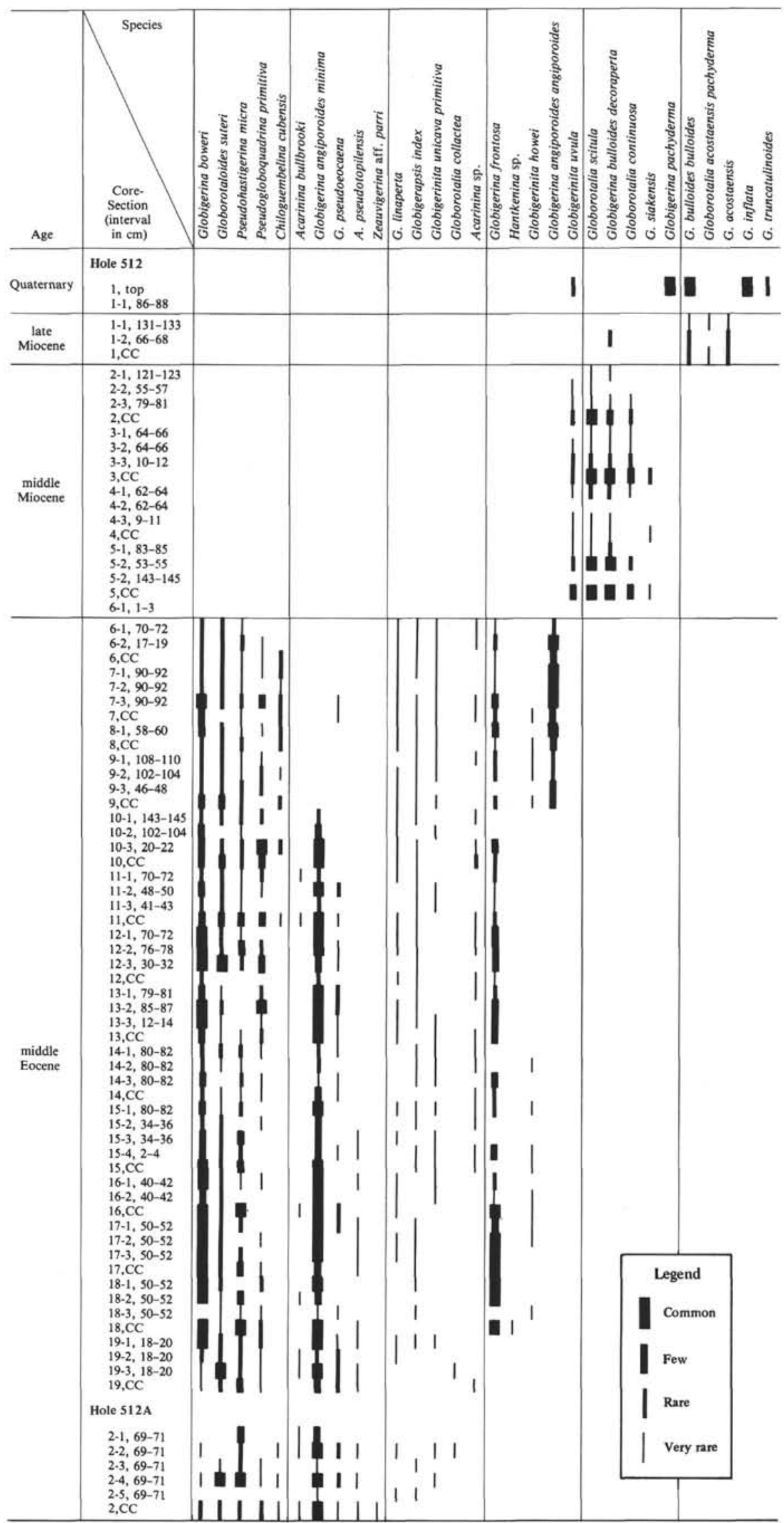

Figure 4. Distribution of planktonic foraminifers in the Cenozoic sediments of Site 512. 


\section{Middle Eocene}

Middle Eocene siliceous-nannofossil oozes were encountered in the interval from Cores 512-6 to 512-19 and in Core $512 \mathrm{~A}-2$. They are characterized by a rather diverse planktonic foraminifer assemblage consisting of more than 20 species.

The basal layers of the section from Sample 512A-2-3, 69-71 cm to Sample 512A-2, CC contain common Globigerina angiporoides minima, Globorotaloides suteri, and Pseudohastigerina micra and rare or very rare Globigerina boweri, G. linaperta, G. pseudoeocaena, Globigerinita unicava primitiva, Acarinina bullbrooki, A. pseudotopilensis, Chiloguembelina cubensis, and Pseudogloboquadrina primitiva (a total of 13 species, including the two undetermined ones.). These sediments are tentatively assigned to the $P$. primitiva Zone of New Zealand, taking also into account "negative" evidence such as the absence of Globigerapsis index, the first appearance of which, according to Jenkins's definition (1971), marks the very base of the $G$. index Zone. The upper boundary of the $P$. primitiva Zone is drawn between Samples 512A-2-3, 69-71 cm and 512A-2-2, 69$71 \mathrm{~cm}$ : the latter contains rare specimens of $G$. index. The evolutionary appearance of this species could, however, have occurred earlier; in that case the $P$. primiti$v a / G$. index zone boundary would occupy a lower position. This suggestion is supported by the presence of some specimens of $G$. index in Sample 512A-2-4, 69-61 $\mathrm{cm}$. Unfortunately, it is impossible to define the exact level of the evolutionary appearance of $G$. index because older sediments were not recovered at Site 512 . Therefore the boundary between these zones is tentative.

In the interval from Sample 512-6-1, 70-72 $\mathrm{cm}$ to Sample 512A-2-2, 69-71 cm, the assemblage of planktonic foraminifers becomes more diverse (about 20 species) and consists of predominant Globigerina boweri, G. frontosa, G. angiporoides minima, Globorotaloides suteri, Pseudohastigerina micra, subordinate Globigerapsis index, Globigerina pseudoeocaena, G. linaperta, Globigerinita unicava primitiva, G. howei, and Pseudogloboquadrina primitiva, and rare and irregularly distributed Chiloguembelina cubensis, Acarinina bullbrooki, $A$. pseudotopilensis, and $A$. sp. In the upper part of this subdivision, Globigerina angiporoides minima is replaced by $G$. angiporoides angiporoides. A single specimen of Hantkenina sp. in Sample 512-18,CC only emphasizes the cool-water, austral character of this microfauna.

Co-occurrence of numerous $G$. boweri and $G$. frontosa with $A$. bullbrooki, A. pseudotopilensis, and Globigerapsis index allows us to correlate these sediments with the lower half of the middle Eocene of the tropical belt (within the G. kugleri Zone to the lower part of the Orbulinoides beckmanni Zone). The co-occurrence of $P$. primitiva, G. index and Globigerina linaperta, and the transition from Globigerina angiporoides minima to $G$. angiporoides angiporoides enables us to attribute the sediments to the Globigerapsis index Zone of New Zealand (Jenkins, 1971). According to Jenkins, Pseudoglo- boquadrina primitiva does not appear in the overlying Globorotalia (Testacarinata) inconspicua Zone of New Zealand. Hence it appears that the upper part of the middle Eocene is missing in the Site 512 section.

\section{Middle Miocene}

The middle Miocene diatomaceous oozes recovered in the interval from Sample 512-2-1, 121-123 cm to Sample 512-5,CC overlie disconformably the middle Eocene deposits and are characterized by very poor planktonic foraminifers (six species). The assemblage is dominated by $G$. scitula and Globigerina bulloides decoraperta and accompanied by Globorotalia continuosa, G. siakensis, and Globigerinita uvula. The presence of Globorotalia continuosa and $G$. siakensis allows us to assign the sediments to the middle Miocene. Almost all of the species just mentioned persist throughout the entire middle Miocene section at Site 512 .

\section{Upper Miocene}

Upper Miocene diatomaceous oozes 8.5 meters thick conformably overlie middle Miocene sediments in the interval from Sample 512-1-1, 131-133 cm to Sample $512-1, C C$. They contain a very poor assemblage of planktonic foraminifers composed of rare to very rare Globigerina bulloides bulloides, G. bulloides decoraperta, and Globorotalia acostaensis. The presence of G. acostaensis makes it possible to assign the sediments to the upper Miocene.

In this interval atypical specimens of $G$. acostaensis with more compact four-chambered tests and a more or less umbilical aperture are present together with characteristic ones. All of these features relate these forms to Globigerina pachyderma. This connection was noted for the first time on Leg 36 by Tjalsma (1977), who referred both Globorotalia acostaensis and Globigerina pachyderma to the genus Neogloboquadrina. The atypical forms may be considered as transitional between the two species.

\section{Quaternary}

The upper $88 \mathrm{~cm}$ of the cored section consists of diatomaceous quartzose sands and pebbles that overlie disconformally the upper Miocene sediments. These are considered Quaternary because Recent cool-water planktonic foraminifers are present. The assemblage consists of Globigerina bulloides bulloides, G. pachyderma, and Globorotalia inflata, accompanied by Globigerinita $u v u$ $l a$ and Globorotalia truncatulinoides. The latter are represented by a low-conical variety as in the Quaternary sediments at Site 511 .

\section{Site 513}

The site is situated on the lower flank of the Mid-Atlantic Ridge to the east of the abyssal plain of the Argentine Basin $\left(47^{\circ} 34.99^{\prime} \mathrm{S}, 24^{\circ} 38.40^{\prime} \mathrm{W}\right.$, water depth $4373 \mathrm{~m}$ ). It is located about 150 miles north of the present-day position of the Polar Front and was chosen to trace the evolution and climatically induced migrations of this oceanic boundary as recorded in the Cenozoic sedimentary sequence. Two holes were drilled. Hole 513 
resulted in 11 cores with an average recovery of approximately $51 \%$. Hole $513 \mathrm{~A}$ was washed down to 85 meters; two cores were taken in the interval from 56.5 to 75.5 meters to fill in recovery gaps in Hole 513 . Then coring was continuous to a basement depth of 380.5 meters.

Planktonic foraminifers are completely absent in the muddy diatomaceous oozes and diatomaceous mud of Hole 513 and Cores 1-12 of Hole 513A. From Core 513A-13 down through a long sequence of slightly calcareous diatomaceous oozes and calcareous nannofossil oozes the foraminiferal content grows in abundance and species diversity, reaching a maximum in the basal layers of the section. Planktonic foraminifers were used to distinguish Oligocene, lower Miocene, and PlioceneQuaternary sediments (Fig. 5).

\section{Oligocene}

Diatomaceous nannofossil ooze and nannofossil ooze with intercalations of chalk, 172 meters thick, were recovered in the interval from Core 513A-16 to Core 513A-33. The lower part of the Oligocene (Cores 24-33) contains a rather diverse microfauna, amounting to 14 species. The assemblage is characterized by predominant Globigerina angiporoides angiporoides, G. aff. linaperta, Globigerinita unicava unicava, and G. unicava primitiva. The remaining assemblage includes, throughout the entire interval, rare and very rare Globorotalia gemma, G. munda, Globorotaloides suteri, Globigerinita martini scandretti and Chiloguembelina cubensis, and, in separate samples only, Globigerina galavisi, G. ouachitaensis, G. praebulloides, G. prasaepis and G. senilis. These sediments can be correlated with the $G$. angiporoides Zone of New Zealand, which belongs to the Lower Oligocene (Jenkins, 1971).

The assemblage of planktonic foraminifers characteristic of the interval from Sample 513A-20-3, 3-5 cm to Sample 513A-23,CC has extremely low diversity. Rare specimens of Globigerina aff. linaperta, G. prasaepis, and G. labiacrassata occur sporadically; their cooccurrence allows us to place the sediments in the upper Oligocene. The remaining part of the section from Sample 513A-16-1, 10-12 cm to Sample 513A-20-2, 72-74 $\mathrm{cm}$ lacks planktonic foraminifers and is Oligocene, according to siliceous microfossil evidence. This interval evidently corresponds to the migration of the Polar Front northward and to the concomitant decrease of planktonic foraminiferal productivity in the surface water.

\section{Lower Miocene}

The interval from Core 12 to Core 15 is marked by a planktonic foraminifer assemblage consisting of only three taxa-Globigerina woodi woodi, G. woodi connecta, and Globigerinita dissimilis. The first two species are dominant and place the sediments in the lower Miocene G. woodi connecta Zone of New Zealand (Jenkins, 1971). Leg 40 data show that at Site 360 (Cape Basin) these species are present together with Globorotalia $\mathrm{ku}$ gleri and Globigerinoides primordius. Their co-occurrence permitted Toumarkine (1978) to correlate the Globigerina woodi connecta Zone with the lower Miocene

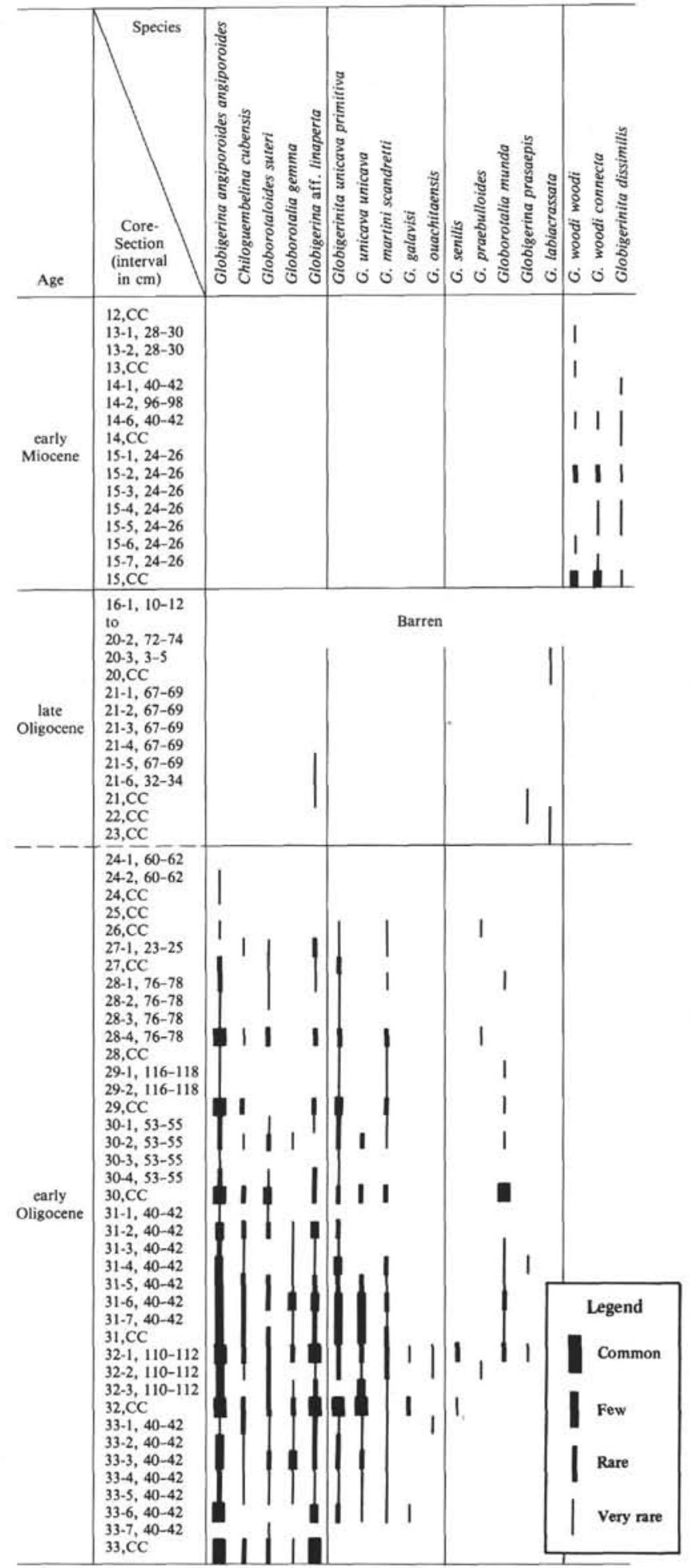

Figure 5. Distribution of planktonic foraminifers in the Cenozoic sediments of Site 513 .

Globorotalia kugleri-Globigerinoides primordius Zone of the tropical-subtropical zonal scheme (Blow, 1969). On this basis the sediments of Cores 12-15 can be attributed to the lowermost Miocene. The Oligocene/lower Miocene boundary is drawn just below Sample 513A- 
$15, \mathrm{CC}$, the first sample containing the species of Globigerina and Globigerinita just mentioned; the underlying sediments lack these forms.

\section{Pliocene-Quaternary}

Pliocene-Quaternary diatomaceous oozes of Hole 513 (Cores 1-9) and Hole 513A (Cores 1-12) are almost barren of planktonic foraminifers except for Samples 513$3-1,133-135 \mathrm{~cm}$ and $513-3-2,38-40 \mathrm{~cm}$, where Globigerina bulloides, G. pachyderma, Globorotalia inflata, and $G$. puncticulata are present. According to Jenkins (1978) and Poore (1978), the latter species does not cross the Pliocene/Pleistocene boundary, but Kennett and Vella (1975) have described it from Pleistocene sediments. This discrepancy prevents us from using the G. puncticulata extinction level for exact definition of the Pliocene/Quaternary boundary. G. truncatulinoides, which could be helpful for this purpose, is absent in the Site 513 Quaternary section. Using siliceous microfossils data, this boundary can be placed at the very base of Core 513-3.

\section{Site 514}

Site 514 was drilled on the lower flank of the Mid-Atlantic Ridge in the eastern Argentine Basin, about 100 miles north of Site 513 and 250 miles north of the present-day position of the Polar Front $\left(46^{\circ} 02.77^{\prime} \mathrm{S} ; 26^{\circ}\right.$ $51.30^{\prime} \mathrm{W}$, water depth $4318 \mathrm{~m}$ ). Together with Site 513, it was selected to provide evidence of Polar Front evolution and its influence on the biogenic productivity and water circulation connected with the formation of the Antarctic ice cover during the late Cenozoic. The site was hydraulic piston cored through Pliocene and Quaternary sediments to a depth of 150.8 meters below the seafloor.

Planktonic foraminifers in the Pliocene-Quaternary siliceous diatomaceous oozes and muds of this site are more numerous and diverse in species composition than those of Site 513. Their stratigraphic distribution is sporadic, reflecting paleoenvironmental changes near the Polar Front during the late Cenozoic. Paleomagnetic and siliceous microfossil data make it possible to date these changes.

\section{Pliocene}

Cores 6-35 penetrated Pliocene diatomaceous ooze and diatomaceous mud with intercalations of nannofossil mud and nannofossil chalk in the lower part of the section. Cores 31-35 (upper Gilbert Epoch) are characterized by the most diverse foraminiferal assemblage: Globigerina bulloides, G. pachyderma, G. aff. apertura, Globorotalia puncticulata, G. scitula, G. aff. scitula, G. inflata, and Globigerinita uvula. In this interval were also found rather diverse benthic calcareous species. This likely reflects a more southerly position of the Polar Front than at present and relatively high productivity of calcareous plankton in surface waters.

Cores 24-30 (latest Gilbert and early Gauss epochs) are almost barren of planktonic (and calcareous benthic) forminifers except in Samples 514-29, CC, 514-28$2,28-30 \mathrm{~cm}$, and $514-28-3,29-31 \mathrm{~cm}$, which contain very rare specimens of Globigerina bulloides, Globorotalia puncticulata, and G. scitula. This interval evidently reflects the migration of the Polar Front to the north and a decrease of calcareous plankton productivity, but the deterioration of the climate was interrupted by a short warming period (Cores 28 and 29).

A low-diversity assemblage of planktonic foraminifers is present irregularly in Cores 18-23 (middle Gauss Epoch). It is represented by Globigerina bulloides, $G$. pachyderma, Globorotalia inflata, G. hirsuta, and $G$. puncticulata. This assemblage, together with relatively rich and diverse benthic foraminifers, suggests milder climatic conditions resulting from the southward migration of the Polar Front.

In the upper part of the Pliocene section (Cores 6-17, the latest Gauss and the Matuyama up to the Olduvai Event) planktonic foraminifers are almost missing. Exceptions are Samples 514-6,CC, 514-15-2, 116-118 cm, 514-15,CC and 514-16,CC, which contain rare specimens of Globigerina pachyderma, Globorotalia inflata, G. hirsuta, and $G$. puncticulata as well as calcareous benthic forms. The interval seems to reflect a northern position of the Polar Front during this time. This period of cooling was complicated by very short moments of insignificant warming at the end of the Gauss Epoch (Cores 15 and 16), just prior to the Olduvai Event (Cores 6 and 7).

The Pliocene/Quaternary boundary placed below Sample $514-5, C C$ is determined by the paleomagnetic data and siliceous microfossils distribution. Low species diversity (or absence) of planktonic foraminifers makes this group of fossils unreliable for precise age determination. Their evidence makes it possible to identify the age of the youngest sediments at Site 514 as PlioceneQuaternary undifferentiated.

As already mentioned, the extinction of Globorotalia puncticulata, according to Jenkins (1978) and Poore (1978) appears to occur at the Pliocene/Quaternary boundary. If so, this boundary should be placed right above Sample 514-6,CC, the last sample containing $G$. puncticulata. The evidence for the age of the overlying sediments in this case is "negative," since Cores 2-5 are barren of planktonic foraminifers. The absence at Site 514 of G. truncatulinoides, a characteristic Quaternary species, further complicates the problem of defining the Pliocene/Quaternary boundary at this site.

\section{Quaternary}

Quaternary diatomaceous oozes in Cores 1-5, corresponding to the normal Brunhes and later Matuyama down to the Olduvai Event, are lacking planktonic foraminifers. Only Sample 514-1,CC contains two speciesGlobigerina pachyderma and Globorotalia inflata, which indicate cool-water conditions near the Polar Front. The cooling which set in at the end of the Gauss Epoch because of the northward migration of the Polar Front was evidently occurring during the Quaternary. A short period of slight warming is noted only at the end of the Brunhes Epoch (Core 1).

Certainly the most precise picture of Polar Front migration and temperature fluctuations is given by the 
character of siliceous microfossils (Ludwig, Krasheninnikov, et al., 1980). Poor assemblages of planktonic foraminifers do not possess such accurate ecologic resolution. But the main trend of their distribution in Pliocene-Quaternary sediments of Site 514 confirms completely a curve of temperature changes based on the analysis of siliceous planktonic microorganisms shown in Figure 6.

\section{MAJOR FEATURES OF CENOZOIC STRATIGRAPHY AND PLANKTONIC FORAMINIFERS OF THE SOUTH ATLANTIC}

Planktonic foraminifers from the Cenozoic sediments recovered by Leg 36 Sites and investigated by Tjalsma (1977) were referred to four Tertiary intervals: upper Paleocene-lower Eocene, Oligocene, lower-middle Miocene, and late Miocene. The combination of materials from Legs 36 and 71 provides an opportunity to widen our knowledge of Cenozoic planktonic foraminifers of the South Atlantic. Leg 36 and Leg 71 sites were drilled within three different areas in this region (Fig. 2). The most important are Sites 327, 329, 511, and 512, which penetrated relatively shallow water calcareous sediments of the Maurice Ewing Bank (water depths from 1519 to $2401 \mathrm{~m}$ ). Sites 513 and 514 lie within the Argentine Basin at water depths of over 4300 meters; only some subdivisions of calcareous-siliceous and siliceous biogenic oozes contain poor planktonic foraminifers. Site 328 lies in the Malvinas Outer Basin, south of the Falkland Fracture Zone (water depth $5103 \mathrm{~m}$ ); calcareous plankton are absent here.

Unfortunately, no site has recovered a complete sequence of Cenozoic sediments and only three of them have reached Mesozoic deposits (Sites 511, 327, and 328). Even a composite section of the Cenozoic has some stratigraphic gaps. At the moment, the succession of Cenozoic foraminiferal assemblages in the southwestern Atlantic can be outlined as follows.

\section{Paleocene}

Assemblages of planktonic foraminifers typical of the interval from the Globigerina eugubina Zone (basal Danian Stage) to the Globorotalia pseudomenardii Zone (upper Paleocene) are still unknown for the Falkland Plateau. A rich assemblage of planktonic foraminifers has been detected only in the uppermost Paleocene sediments of Site 329, which can be correlated to the $G$. velascoensis Zone. We investigated nine samples in the interval from Sample 329-33-4, 131-133 cm to Sample 329-32-4, 43-45 cm. They contain abundant Acarinina acarinata, A. mckannai, A. intermedia, A. esnaensis, A. soldadoensis, G. perclara, G. reissi, G. imitata, G. convexa, Globigerina velascoensis, G. nana, G. incisa, G. aquiensis, Chiloguembelina wilcoxensis, and some other representatives of Acarinina and Globigerina; $G$. australiformis appears at the top of these layers. Assemblages in which either Acarinina or Globigerina predominates also alternate.

The sediments with the planktonic foraminiferal assemblage can be correlated with upper Paleocene depos- its of the U.S.S.R. (Crimea, North Caucasus) located at the northern rim of the subtropical belt $\left(43-47^{\circ} \mathrm{N}\right)$. In that area, upper Paleocene deposits are characterized by prevalent Acarinina, Globigerina, and nonkeeled Globorotalia species and are subdivided into two zonal units: the Acarinina mckannai Zone with rare G. pseudomenardii and the $A$. acarinata Zone with the index species A. soldadoensis and rare G. velascoensis and G. acuta. The latter corresponds definitely to the $G$. velascoensis Zone of the tropical belt. Simultaneous examination of planktonic foraminifers and nannofossils from the North Caucasian Paleocene revealed that the $A$. acarinata Zone was an equivalent of the Discoaster multiradiatus Zone (Krasheninnikov and Muzylöv, 1975).

Upper Paleocene planktonic foraminifers of Site 329 are similar to those of the A. acarinata Zone of the North Caucasus, differing in their low taxonomic diversity, which reflects colder water conditions. Hence, sediments of Site 329 with these foraminifers can be assigned to the G. velascoensis Zone of the tropical scale. Nannofossils of the $D$. multiradiatus Zone supports this conclusion (Wise and Wind, 1977).

Tjalsma (1977) also attributed these sediments to the G. velascoensis Zone but assigned the basal layers (from Sample 329-33-4, 100-102 cm to Sample 329-33,CC) to the $G$. pseudomenardii Zone. In our opinion, the numerous $A$. acarinata and $A$. soldadoensis developed in these layers indicate the $A$. acarinata Zone (i.e., the $G$. velascoensis Zone). At the same time, the presence of numerous specimens of $A$. mckannai suggests that we are not far from the boundary with the underlying A. mckannai Zone (i.e., G. pseudomenardii Zone).

In the upper Paleocene of Site 329, Tjalsma (1977) singled out $A$. praepentacamerata (Schutzkaya), A tadjikistanensis djanensis Schutzkaya, Globigerina varianta Subbotina and Globorotalia planoconica Subbotina. We believe that these species are lacking here. Under these names Tjalsma described other representatives of planktonic foraminifers. Besides, the species mentioned do not exist at the stratigraphic level of the $A$. acarinata Zone: the first three taxa are developed in older deposits (lower-middle Paleocene), the last one in younger sediments (lower Eocene). The species A. nicoli (Martin), as Tjalsma sees it, corresponds to $A$. acarinata Subbotina, which is the type species of the genus Acarinina. The synonymy of these two species is a very complicated question, because Martin (1943) did not give the precise stratigraphic position of $A$. nicoli within the Lodo Formation, California. This Formation includes sediments of a wide stratigraphic interval (upper Paleocene-lower Eocene) which is characterized by several independent 4-4.5-chambered species of the A. acarinata group. Therefore, we prefer to use the name $A$. acarinata, the stratigraphic range of which is well known (abundant in the $G$. velascoensis Zone, upper Paleocene, and subordinate in the G. subbotinae Zone, lower Eocene).

\section{Eocene}

Lower Eocene planktonic foraminifers are poorly known in the Falkland Plateau area. At Site 329 the upper Paleocene is overlain by sediments with very similar 


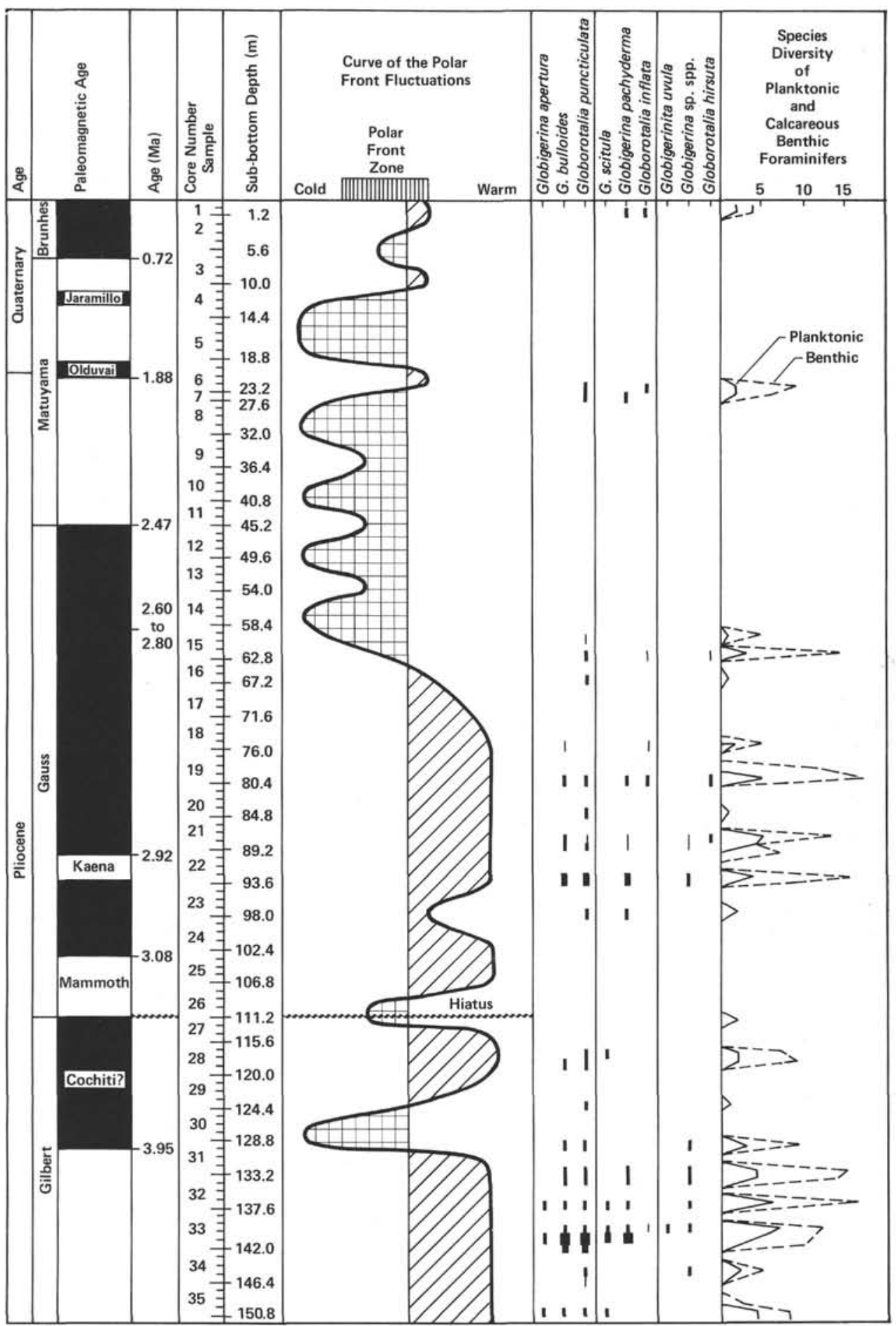

Figure 6. Relation of the paleomagnetic scale and curve of Polar Front fluctuations (based on siliceous microfossils) to the distribution of planktonic foraminifers.

microfauna: Acarinina acarinata, A. soldadoensis, $A$. esnaensis, Globorotalia perclara, G. reissi, G. australiformis, Globigerina nana, G. incisa, and $G$. aquiensis. Together with these species in Samples 329-32-1, 133-135 $\mathrm{cm}$ and 329-32-1, 91-93 cm we found very rare and small Pseudohastigerina wilcoxensis, Globorotalia aequa, G. wilcoxensis, and $A$. pseudotopilensis. This foraminifer- al assemblage places the sediments in the very base of the lower Eocene. We agree with the opinion of Tjalsma (1977); he also detected rare G. subbotinae here.

At Site 327 Tjalsma (1977) discovered poorly preserved shells and clayey casts of the A. mckannai group, A. primitiva, G. australiformis, and $G$. caucasica and assigned sediments to the upper lower Eocene. The lat- 
ter species is a good indicator of this age but bad preservation of the microfauna makes the age determination approximate.

Middle Eocene sediments were drilled only at Site 512, where their contact with the upper Eocene was absent and their basal layers were not reached. Rather diverse planktonic foraminifers testify to the lower and middle parts of the middle Eocene (within the section from the Globigerapsis kugleri Zone to the lower part of the Orbulinoides beckmanni Zone of the tropical scheme). At the base of the section foraminiferal assemblages consist of Globigerina boweri, G. angiporoides minima, G. linaperta, G. pseudoeocaena, A. bullbrooki, A. pseudotopilensis, Pseudogloboquadrina primitiva, Pseudohastigerina micra, and Globorotaloides suteri; evidently, these sediments correspond to the Pseudogloboquadrina primitiva Zone of New Zealand. Upward in the section, these species are accompanied by Globigerapsis index, Globigerina frontosa, and Globigerinita howei; the sediments can obviously be correlated to the Globigerapsis index Zone of New Zealand.

Upper Eocene sediments penetrated at Site 511 make a gradual transition to the Oligocene oozes and overlie unfossiliferous clays. Therefore, their stratigraphic scope is unknown but one can suggest that the sediments comprise the latest Eocene. The planktonic foraminiferal assemblage includes common to few Globigerina angiporoides angiporoides, G. aff. linaperta, G. tripartita, G. galavisi, Globigerapsis index, G. aff. tropicalis, Globigerinita pera, G. martini, Globorotaloides suteri, and Chiloguembelina cubensis. Representatives of Acarinina and Pseudogloboquadrina are completely missing. Apparently, sediments with these foraminifers correspond to the upper Globigerina linaperta Zone and the lower $G$. brevis Zone of New Zealand.

\section{Oligocene}

Oligocene sediments recovered both on the Falkland Plateau and in the Argentine Basin can be informally subdivided into lower and upper Oligocene on the basis of planktonic foraminifers.

The lower Oligocene assemblage of planktonic foraminifers is moderately diverse and consists mainly of Globigerina angiporoides, G. aff. linaperta, G. officinalis, G. ouachitaensis, G. prasaepis, Globorotalia gemma, G. munda, Globigerinita unicava, G. martini, Globorotaloides suteri, and Chiloguembelina cubensis (Sites 329,511 , and 513). This microfauna restricts the sediments to the Globigerina tapuriensis and G. ampliapertura zones of the tropical zonal scheme, or to the upper part of the $G$. brevis and $G$. angiporoides zones of New Zealand.

The upper Oligocene is characterized by a very poor assemblage of planktonic foraminifers, including $G$. labiacrassata, G. brazieri, G. prasaepis, Globigerinita unicava, G. dissimilis, and Globorotaloides suteri (Sites 329 and 513). Globigerina angiporoides disappears. These peculiarities of the taxonomic composition of foraminifers place the sediments within the $G$. euapertura Zone of New Zealand.

\section{Neogene-Quaternary}

All Miocene, Pliocene, and Quaternary assemblages of planktonic foraminifers are united by one general feature: exceedingly low species diversity.

The youngest Miocene assemblage was identified in the Argentine Basin (Site 513) and is represented by Globigerina woodi woodi, G. woodi connecta, Globigerinita dissimilis, and G. unicava, restricting these sediments to the Globigerina woodi connecta Zone of New Zealand (Jenkins, 1971). As has already been mentioned, Toumarkine (1978), considering the co-occurrence of these species with Globorotalia kugleri and Globigerinoides primordius (Site 360, Cape Basin), correlated the Globigerina woodi connecta Zone to the Globigerinoides primordius-Globorotalia kugleri Zone of the tropical-subtropical realm (the lowermost Miocene).

An assemblage of planktonic foraminifers consisting of abundant Globorotalia miozea miozea and Globigerina bulloides s.l. covered by a heavy crust of secondary calcite and accompanied by rare Globorotalia zealandica incognita and Globigerinita glutinata (Site 329, Maurice Ewing Bank) can be attributed to the upper part of the lower-middle Miocene.

The middle Miocene planktonic foraminifers encountered at Site 512 consisted of Globorotalia siakensis, G. continuosa, G. scitula, G. zealandica, Globigerina bulloides, and Globigerinita uvula.

Upper Miocene sediments of Sites 329 and 512 contain only Globorotalia acostaensis, Globigerina bulloides, and forms close to G. pachyderma.

Pliocene sediments of the Argentine Basin (Sites 513 and 514) are almost barren of planktonic foraminifers. Only discrete layers contain the assemblage Globorotalia inflata, G. puncticulata, G. scitula, Globigerina pachyderma, and $G$. bulloides.

Quaternary sediments are present at almost all southwestern Atlantic sites. The planktonic foraminiferal assemblage includes low-conical forms of Globorotalia truncatulinoides together with $G$. inflata, G. scitula, Globigerina pachyderma, G. bulloides, G. quinqueloba, Globigerina glutinata, G. uvula, and Globorotalita aff. iota.

Cenozoic planktonic foraminifers of the Falkland Plateau and Argentine Basin belong to the high-latitude Austral Province. They are marked by low or very low taxonomic diversity. Paleogene assemblages consist mainly of representatives of Globigerina, Acarinina and nonkeeled Globorotalia, with a minor amount of Globigerapsis, Globigerinita, Globorotaloides, Pseudohastigerina, and Chiloguembelina. But the species diversity of these genera is again very low. Representatives of keeled and conical Globorotalia are extremely rare or absent, and species of Hantkenina, Cribrohantkenina, Orbulinoides, and Globigerinatheca are missing. Neogene-Quaternary foraminiferal associations are still poorer; they include several species of Globigerina, Globigerinita, and nonkeeled Globorotalia. All representatives of Globigerinoides, Praeorbulina, Orbulina, keeled Globorotalia, Globoquadrina, Globigerinella, Pullenia- 
tina, Sphaeroidinellopsis, and the like are missing completely.

Nevertheless, the bulk of the taxa is made up of species that are widely distributed in subtropical and temperate areas of the World Ocean. The quantity of endemics of the Southern Hemisphere high latitudes is insignificant: Globorotalia australiformis, G. zealandica, Globigerina labiacrassata, and $G$. brazieri. In our opinion, this group also includes the middle Eocene Pseudogloboquadrina primitiva Finlay). A species very often described from the upper Paleocene-lowermost Eocene of the Northern Hemisphere under the name A. primitiva (Finlay) apparently has no relation to the southern high-latitude $P$. primitiva. Certainly, high-latitude planktonic foraminifers of the Northern Hemisphere have not been thoroughly studied. Perhaps in the future we shall find New Zealand and Australian species among them.

A very important problem concerns the stratigraphic ranges of planktonic foraminifers which have a wide geographical distribution. We do not know exactly whether they are characterized in the area of the Falkland Plateau and Argentine Basin by their full stratigraphic intervals (biozones) or by shortened partial intervals (epibols or teilzones). Incomplete Cenozoic sections and a paucity of planktonic foraminifers preclude an answer to this question. But we must keep in mind the possibility that in the high-latitude belt some species with a universal geographic distribution are characterized by incomplete ranges that are connected with climatic fluctuations.

All these features of the Austral microfauna diminish the stratigraphic resolution of Cenozoic planktonic foraminifers and create difficulties in correlation to warmwater areas. As a result, the Paleogene can be subdivided mainly into subseries. The same picture holds for the Neogene, but here even these subdivisions are not very reliable.

\section{CENOZOIC GEOLOGICAL HISTORY OF THE SOUTHWESTERN ATLANTIC: PALEOENVIRONMENTAL AND PALEOCLIMATIC ANALYSIS}

Every group of fossils (foraminifers, radiolarians, diatoms, spores and pollen, etc.) found in the Cenozoic sediments of the Falkland Plateau and Argentine Basin contributes to the general picture of the geological history and paleoenvironmental and paleoclimatic changes in this area and characterizes geological phenomena from different aspects. Some aspects of the Cenozoic events have already been discussed by the authors (Basov and Krasheninnikov, this volume) in their consideration of benthic foraminifers. Here we shall try very briefly to outline the problems in light of the evidence provided by planktonic foraminifers.

In spite of the very irregular distribution of planktonic foraminifers and their general impoverishment in Cenozoic sediments (a fact which prevents high stratigraphic resolution), these foraminifers yield data not only for stratigraphic subdivision but also for tracing the major geologic, climatic, and oceanographic chang- es and events within the southwestern Atlantic. What is more, the irregularity in their distribution may itself sometimes serve to indicate of environmental instability.

\section{Geological History}

The oldest Cenozoic sediments were recovered at Sites 511, 327, and 329, drilled on the Maurice Ewing Bank (Fig. 2). The Cenozoic sequence begins with a pile of pelagic noncalcareous clays (Site 511) or zeolitic clays (Site 327) of Paleocene age, lacking planktonic foraminifers and overlying, with a distinct unconformity, Maestrichtian calcareous oozes. The nature of the hiatus at the Mesozoic/Cenozoic boundary has been discussed by Sliter (1977), Ludwig, Krasheninnikov, et al. (1980), and Basov and Krasheninnikov (this volume). Apparently, strong bottom currents existing at that time scoured the Mesozoic sediments. This hiatus is usually marked by dissolution facies of different thicknesses and ages. At Site 511 pelagic clays 15 meters thick belong to the Paleocene-Eocene that is tentatively defined by means of radiolarians. Zeolitic clays and diatom-radiolarian oozes 57 meters thick at the base of the Cenozoic sequence of Site 327 are assigned to the middle-late Paleocene based on siliceous microfossils, coccoliths, and foraminifers. Shallower water upper Paleocene sediments penetrated by Site 329 at the eastern edge of the Maurice Ewing Bank have a quite different composition: they are represented by nanno-micrite oozes 10 meters thick with abundant planktonic foraminifers. Unfortunately their contact with Mesozoic deposits was not reached.

At Site 328 in the Malvinas Outer Basin, the lower part of the section is composed of a pile of zeolitic clays and claystones about 260 meters thick and containing no planktonic microfossils. The assemblage of arenaceous benthic foraminifers, which is indicative of abyssal depth, dates the sediments as Late Cretaceous-late Eocene (Tjalsma, 1977).

Lower Eocene sediments of Site 329, consisting of nannomicrite oozes with rich planktonic foraminifers, conformably overlie the upper Paleocene. Their visible thickness is about 1 meter, but the boundaries of the lower Eocene cannot be determined exactly because of spot coring. In addition to this site, lower Eocene sediments were recovered at Site 327 , where they are represented by zeolitic clays 10 meters thick, with poor planktonic foraminifers; contact with the upper Paleocene is gradational.

Middle Eocene sediments 69 meters thick were drilled only at Site 512, where they are composed of nannofossil siliceous oozes with rather diverse planktonic foraminifers. One cannot exclude the possibility that middle Eocene sediments are present within the thin pile of pelagic clays at Site 511 that has been tentatively assigned a Paleocene-Eocene age. If so, the thickness of the middle Eocene here does not exceed several meters. At the other sites drilled on the Falkland Plateau, middle Eocene time corresponds to the hiatus which evidently not only occupies this interval but also extends over the early and late Eocene. 
Nanno-rich upper Eocene diatomaceous oozes with subordinate amounts of planktonic foraminifers $(38 \mathrm{~m}$ thick) were sampled only at Site 511 .

Oligocene sediments were recovered within all three areas under study, but differ somewhat in composition, thickness, and age.

The oldest Oligocene layers conformably overlying the upper Eocene were penetrated on the Maurice Ewing Bank at Site 511. They are about 145 meters thick, are composed of diatomaceous and nanno-diatomaceous oozes containing a moderately diverse assemblage of planktonic foraminifers, and belong to the upper part of the Globigerina brevis Zone and the G. angiporoides Zone of New Zealand. The upper part of the Oligocene is missing here. At Site 329, Oligocene deposits are represented by micrite nanno chalk 38 meters thick. Basal layers are assigned to the $G$. angiporoides Zone (lower Oligocene); upward in the section this species disappears and sediments are assigned to the upper Oligocene (Tjalsma, 1977).

In the Malvinas Outer Basin (Site 328) Oligocene sediments about 25 meters thick are composed of zeolitic clays and siliceous clayey oozes separated by a hiatus from the underlying Upper Cretaceous-Eocene deposits. The age of the lowermost part of these sediments was determined by diatoms to be early Oligocene, that of the upper part as late Oligocene; a hiatus exists between them (Gombos, 1977).

In the Argentine Basin (Site 513) the Oligocene sequence is more complete. A lower part consisting of nannofossil oozes 76 meters thick may be correlated to the G. angiporoides Zones of the Falkland Plateau. The overlying pile of diatomaceous and diatomaceous nannofossil oozes with very impoverished planktonic foraminifers is assigned to the upper part of the Oligocene. The total thickness of the Oligocene sediments at Site 513 is nearly 200 meters.

The Miocene sediments penetrated by Sites 512,513 , 328 , and 329 are characterized by more or less uniform lithologic composition but their different thicknesses reflect the extremely complicated evolution of the bottom currents.

The most complete Miocene sequence was recovered at Site 329 near the top of the Maurice Ewing Bank. The basal layers of the Miocene at this site overlie, without visible unconformity, upper Oligocene sediments; like them, they are composed of nanno-micrite chalk. But planktonic foraminifers, which indicate a latest early Miocene-middle Miocene age for these sediments, testify to an obscure unconformity. Because of spot coring, the thickness of this Miocene sediment member may be estimated as approximately 30 meters.

A gradual transition of Oligocene to lower Miocene sediments is observed in the Argentine Basin (Site 513); here deep-water diatomaceous nannofossil oozes 28.5 meters thick contain poor planktonic foraminifers.

Middle Miocene sediments are present at Sites 512 and 329 and are everywhere composed of diatomaceous nannofossil oozes except in their lower part at Site 329, where they are diatomaceous nannochalk. At Site 512, middle Miocene oozes 19 meters thick rest with a signifi- cant hiatus on the middle Eocene. At Site 329, they are almost 150 meters thick and are connected with older sediments by a gradual transition. Middle Miocene sediments are characterized by very impoverished assemblages of planktonic foraminifers.

Upper Miocene sediments were recovered at Sites 512,513 , and 329. Unlike the middle Miocene deposits they are somewhat different in composition: at Sites 512 and 513 they are diatomaceous oozes, at Site 329 nannodiatom and diatom micrite oozes. The thickness varies widely, from 200 meters on the western slope of the Maurice Ewing Bank (Site 329) to only 8.5 meters on the eastern margin of the Bank (Site 512). A planktonic foraminiferal assemblage of very low diversity is present in calcareous sediments of this age. Only rare, agglutinated benthic foraminifers were found in deep-water diatomaceous oozes of the Argentine Basin (Site 513). These are attributed to the late Miocene on the basis of siliceous microfossils.

To summarize, the Miocene siliceous carbonate sediments within the Falkland Plateau area vary in thickness from 19 meters (Site 512) to approximately 350 meters (Site 329). In the Argentine Basin (Sites 513 and 514), the total thickness of diatomaceous and siliceous nannofossil ooze is about 80 meters. In the Malvinas Outer Basin (Site 328) Miocene time is marked by the accumulation of about 16.5 meters of siliceous clayey ooze. At Sites 511 and 327, Miocene sediments were removed by erosional processes.

Pliocene sediments are almost absent on the Maurice Ewing Bank (Sites 511, 512, 327, and 329). The most complete sequences were obtained in the Argentine Basin, where diatomaceous clayey and muddy diatomaceous oozes form a pile 90 meters thick at Site 513 and 130 meters thick at Site 514. The oozes are almost barren of planktonic foraminifers, usually incorporating only impoverished assemblages of benthic, agglutinated, deep-water species. Only discrete layers contain a lowdiversity assemblage of planktonic foraminifers. In the Malvinas Outer Basin (Site 328) was a thin sequence (about $5 \mathrm{~m}$ ) of diatomaceous ooze barren of planktonic foraminifers; it is assigned to the Pliocene on the basis of siliceous microfossil evidence.

Quaternary sediments are present at all southwestern Atlantic sites, being thickest in the Argentine Basin. They are composed of diatomaceous clays $(20 \mathrm{~m}$ thick at Site 514 and $30 \mathrm{~m}$ thick at Site 513). At the other sites on the Maurice Ewing Bank and in the Malvinas Outer Basin the Quaternary sediments are insignificant in thickness and consist of siliceous ooze with poor planktonic foraminifers.

Sediment distribution patterns indicate that the $\mathrm{Ce}$ nozoic paleorelief of the Falkland Plateau was very similar to the Recent one. Calcareous Paleogene and Neogene sediments with variable amounts of siliceous material (Sites 329 and 512) are limited to relatively shallow water heights on the Maurice Ewing Bank (water depth $1500-1800 \mathrm{~m}$ ). At depths of 2400-2500 meters they are replaced by deeper water siliceous oozes with a subordinate amount of calcareous material (Sites 511 and 327). Abyssal siliceous oozes and zeolitic clays are typical of 
the Cenozoic of the Malvinas Outer Basin (water depth over $5000 \mathrm{~m}$ ).

Biogenic Oligocene and Neogene sediments of the Argentine Basin (Sites 513 and 514) have a distinctly pelagic deep-water character. Only the lower Oligocene is calcareous, directly overlying basaltic basement. At that time the water depth was less significant and only by oceanic subsidence did it reach its present abyssal value (over $4300 \mathrm{~m}$ ).

The most pronounced feature of the Cenozoic sediment sections of the Falkland Plateau is their fragmentary character. Every section is marked by many gaps and hiatuses. Periods with high rates of biogenic sedimentation (the lower Oligocene at Site 511 is about 160 $\mathrm{m}$ thick; the Miocene at Site 329 is over $350 \mathrm{~m}$ thick) alternated with periods of intense underwater erosion. In contrast, Oligocene-Neogene sections of the Argentine Basin are rather complete, with discrete gaps of short duration.

Obviously bottom currents have affected the Falkland Plateau throughout Cenozoic time, but their intensity has varied significantly. The limited number of holes allows one to estimate periods of strong erosion in only a preliminary fashion.

The first period of erosion and nondeposition took place at the Maestrichtian/Paleogene boundary and embraced the lower and middle Paleocene. In the upper Paleocene the conditions of sedimentation were more stable (Sites 329, 327) and the Paleocene/lower Eocene contact is gradational. Distribution of the middle Eocene (Site 512) and upper Eocene (Site 511) is very irregular; Oligocene sediments are developed over larger areas of the Plateau, resting conformably (Site 511) or unconformably on older deposits (Sites 329 and 328). Therefore, one can suggest that erosion activity intensified at the Eocene/Oligocene boundary, where an essential part of the Eocene sediments is washed out.

In the Falkland Plateau realm the Neogene sediments are characterized by very sporadic distribution; they are everywhere separated by a gap from older deposits. At Site 329 such a hiatus is observed between the Oligocene and Miocene. By that time (the Oligocene/Miocene boundary) the circum-Antarctic current was established. This current evidently intensified erosional processes within the Maurice Ewing Bank, preventing or limiting the sediment accumulation. As a result, the Neogene sediments on the Bank are fragmentary (Site 512) or completely missing (Sites 511,327 , and 330). An exception is Site 329, in which the Miocene section is more than 350 meters thick. Seismic reflection profiles through this site show that the Miocene deposits occupy the restricted area surrounding it (Barker, Dalziel, et al., 1977). Several hiatuses are also observed within a thin veneer of Miocene-Quaternary sediments at Sites 511, 512, and 328.

Hiatuses are also traced in Neogene deep-water sediments of the Argentine Basin. At Site 513 a gap separates the lower and upper Miocene; at Site 514 there is a gap within the Pliocene (between the Gilbert and Gauss epochs).

\section{Paleoclimatic Events}

As is well known, planktonic foraminifers are a very useful tool for paleoclimatic reconstructions. Planktonic foraminifers of high latitudes are especially important because they reflect the most pronounced climatic fluctuations.

The first attempt at such a reconstruction in the Falkland Plateau realm was made by Tjalsma (1977). Following Jenkins $(1967,1973)$ he used foraminiferal species diversity for estimating relative temperature changes. Taking into account Leg 36 and Leg 71 data, the Cenozoic temperature curve can be summarized in the following way.

At the Mesozoic/Cenozoic boundary, a definite drop in temperature occurred. All representatives of keeled globotruncanids disappeared in the Maestrichtian sediments of the Falkland Plateau (Krasheninnikov and Basov, this volume). Unfortunately, we do not know the character of planktonic foraminifers of the early and middle Paleocene in this area; thus we cannot estimate the peculiarities of the temperature regime during the earliest Cenozoic.

Abundant and rather diverse planktonic foraminifers indicate relatively warm climatic conditions for the late Paleocene-early Eocene. These assemblages include different species of Globigerina, Acarinina, and nonkeeled Globorotalia together with rare specimens of keeled Globorotalia. These associations are the richest among all Cenozoic foraminiferal assemblages of the Falkland Plateau; correspondingly, the late Paleocene-early Eocene temperatures were the climatic acme of the Cenozoic for this area. Since that time the climate of the southwestern Atlantic has progressively deteriorated. It is difficult to compare the climatic conditions of Maestrichtian and late Paleocene-early Eocene time, but one fact appears very important: upward in the section calcareous nanno-foraminiferal Maestrichtian oozes were replaced by radiolarian clays and diatom-radiolarian oozes (Sites 327 and 511) that may testify to cooler climatic conditions in the late Paleocene-early Eocene than in the late Mesozoic.

Planktonic foraminifers of the middle Eocene are rather numerous and diverse. They include representatives of Globigerapsis, Acarinina, and Pseudogloboquadrina, but keeled Globorotalia has disappeared. Siliceous microfossils are widely developed even in relatively shallow water sediments (Site 512). All these data point to a moderately warm water regime, but there has been a clear diminution of surface temperatures since the late Paleocene-early Eocene.

The gradual cooling evidently continued in the late Eocene, as is evidenced by the further decrease of foraminiferal species diversity and abundance as well as the disappearance of moderately warm water species (Site 511). This seems to contradict the oxygen isotope data from New Zealand (Devereux, 1967, 1968), which show a gradual increase in temperature during the late Eocene. Such a discrepancy between the oxygen isotope data and the character of the planktonic foraminifers 
was noted by Jenkins (1973), who assumed that the late Eocene high temperatures should be revised. It is possible that a short warming took place at the beginning of the late Eocene whereas sediments at Site 511 belong to the latest Eocene.

The Eocene/Oligocene boundary within the Falkland Plateau is marked by a pronounced change in sediment composition from the mainly carbonate to siliceous. In the planktonic foraminiferal fauna, temperate and coldwater elements dominate, reflecting the global decline of surface and bottom-water temperatures (Shackleton et al., 1975). It is quite possible that the sharp climatic deterioration near the Eocene/Oligocene boundary is related to the formation of the Antarctic ice cover (Kennett, Houtz, et al., 1975) and, as a consequence, to a cold-water current which could have been a predecessor of the Antarctic Circumpolar Current, which formed in its ultimate shape in the latest Oligocene, after the opening of the Drake Passage. The hiatus at the Eocene/Oligocene boundary recorded in many sites of the Southern Hemisphere high latitudes during Legs 28,29 , and 36 (Hayes, Frakes, et al., 1975; Kennett, Houtz, et al., 1975; Barker, Dalziel, et al., 1977) evidently could have been evoked by this current.

The Oligocene assemblage of planktonic foraminifers at Sites 511 and 513 is characterized by a species diversity similar to the upper Eocene, but cosmopolitan, tolerant species of Globigerina, Globigerinita, Globorotaloides, and nonkeeled Globorotalia predominate. Basal Oligocene layers at Site 511 contain a poor foraminiferal fauna (cold episode). Diversity increases somewhat in the middle part of the Globigerina angiporoides Zone of Sites 511 and 513 (temperate episode). Jenkins (1973), reporting the increase of the species diversity in the upper $G$. angiporoides Zone of New Zealand, regarded it as a reflection of a short-term warming trend during the early Oligocene.

This warming changed somewhere in the late early Oligocene to a relatively long period of cooling marked by a very impoverished microfauna of the uppermost $G$. angiporoides Zone (Sites 511 and 513). This trend resulted in the sharp decrease of the species diversity of foraminifers and even in their complete disappearance in the late Oligocene, after the G. angiporoides Zone interval (Site 513). This deterioration of climate within the Falkland Plateau and Argentine Basin area evidently reflects the late Oligocene glaciation in the Antarctic.

Planktonic foraminifers in Neogene sediments are significantly less diversified compared to those of the late Paleocene-early Oligocene, and their distribution is very irregular. Foraminiferal assemblages consist of three to six species. Taxonomic composition is so poor that it is difficult to trace the distinct, progressive reduction in the species diversity of warm-water microfauna throughout the Neogene. Siliceous plankton become the most useful tool for restoring Neogene climatic history; planktonic foraminifers in high latitudes play a subordinate role.

The lowermost Miocene sediments encountered at Site 513 contain a very impoverished foraminiferal assemblage of three species, which are rare to few in number. Evidently this event corresponds to a short period of slight warming followed by a cold interval in the late Oligocene.

There is some increase of foraminiferal diversity to five or six species in sediments of the upper part of the lower-middle Miocene (Site 329) and in the middle Miocene oozes of Site 512. These assemblages may be connected with the well-known interval of warming at the end of the early Miocene and the beginning of the middle Miocene. Data on the Falkland Plateau are consistent with the warming trend for this time that appears on Devereux's (1967) paleotemperature curve and with Shackleton and Kennett's (1975) data for Site 277, Leg 29.

Upper Miocene sediments of Sites 329 and 512 are characterized by two to three species of planktonic foraminifers; in deep-water oozes of Site 513 they are absent. The cold climatic conditions of the late Miocene are strongly expressed.

In the Pliocene sediments penetrated by Leg 71 sites planktonic foraminifers are almost absent. The discrete layers at Site 514 in the Argentine Basin, with their impoverished assemblages, reflect the fluctuation of the Antarctic Convergence (the Polar Front) which had already formed by this time. Its most southern position, expressed in the most diverse, abundant, and well preserved planktonic foraminiferal assemblage, which amounts to six to eight species, is recorded during the late Gilbert and early Gauss epochs (Fig. 6). These warm periods seem to be regional in character. Such an assumption is supported by the oxygen isotope data from DSDP Site 284, Tasman Sea (Kennett and Vella, 1975; Shackleton and Kennett, 1975) and by the distribution of silicoflagellates in Sites 266 and 274 from the Ross Sea and East Antarctica (Ciesielski and Weaver, 1974). Two warm periods were separated by a shortterm cooling within the latest Gilbert and earliest Gauss epochs; this cooling period is marked by the accumulation of diatomaceous clay barren of calcareous microfossils. An irreversible climatic deterioration was established in the late Pliocene (late Gauss), corresponding to a northward migration of the Polar Front. This cooling, evidenced by siliceous microfossils (Ciesielski and Weaver, this volume), caused calcareous plankton productivity to decrease and probably was responsible for the consequent rise in the level of the CCD and the absence of planktonic and calcareous benthic foraminifers in the upper Pliocene-Pleistocene sediments (Site 514). This climatic deterioration corresponds to the suggested onset of glaciation in the Northern Hemisphere (Berggren, 1972), to the first glaciation in the Sierra Nevada Mountains in North America (Curray, 1966), and to the lowering of the sea level (Vail and Hardenbol, 1979). The deterioration was interrupted by brief warmings near the Pliocene/Pleistocene boundary and at the end of Pleistocene (late Matuyama and Brunhes epochs, respectively) marked by layers with more numerous and diverse planktonic and calcareous benthic foraminifers.

\section{SOME PROBLEMS OF HIGH-LATITUDE STRATIGRAPHY AND PALEOCLIMATOLOGY}

Studies of Cretaceous and Cenozoic planktonic foraminifers have shown that in the warm-water areas of the 
world (within $40-45^{\circ}$ north and south latitudes) there is a universal zonal stratigraphy. In each biostratigraphic zone the assemblages of planktonic foraminifers are certain to change, depending on bionomic conditions and climatic belts. Theoretically, these zones can help in the adoption of universal stratigraphic units of a higher rank, i.e., stages, subseries, series, etc. This has already been realized to a considerable extent within the Deep Sea Drilling Project. Such a stratigraphic scheme enables us to analyze all geological and paleoclimatic processes on the same chronological basis and on a subglobal scale.

What is the stratigraphic scheme of the Cretaceous and Cenozoic beyond the warm-water area of the world? What chronostratigraphic units can be identified within the high-latitude realm, using planktonic foraminifers and other planktonic micro-organisms?

The stratigraphic resolution of planktonic foraminifers of the Falkland Plateau and the Argentine Basin gradually decreases throughout Cretaceous and Cenozoic time. We can distinguish stages in sediments of the upper Lower Cretaceous and the Upper Cretaceous, but cannot precisely identify boundaries; zones are not separated (Krasheninnikov and Basov, this volume). Subseries, well grounded paleontologically, are established in the Paleogene. The Miocene also yields subseries, but they are very poorly substantiated by planktonic foraminifers. The Pliocene is singled out as a series; its characteristics, however, are not reliable enough. What are the prospects for working out a detailed stratigraphy of the Cretaceous and Cenozoic at the high latitudes of the South Atlantic? Here we have to face a paradoxical fact.

In a warm climate, calcareous plankton (foraminifers, nannoplankton) are of particular importance. In the process of cooling, their stratigraphic resolution decreases and the defining role of calcareous microorganisms passes to siliceous plankton, which guarantee a detailed subdivision. In Cretaceous sediments of the Falkland Plateau calcareous plankton are already considerably impoverished; it is impossible to distinguish zones, and stage boundaries are identified only approximately. In addition, siliceous plankton are still very poorly developed, and there is no paleontological group that promises to provide a detailed stratigraphy of Cretaceous sediments of the Falkland Plateau.

In the Paleocene, a significant element of the Falkland Plateau sediments is siliceous plankton. In the Eocene and Oligocene the diatom-radiolarian oozes are widely distributed. In the Neogene, this type of sediment predominates both on the Falkland Plateau and in the Argentine Basin. Radiolarians, diatoms, and silicoflagellates allow the subdivision of Cenozoic deposits into smaller units (Gombos, 1977; Busen and Wise, 1977; chapters by Gombos and Ciesielski; Shaw and Ciesielski; Ciesielski; and Weaver, this volume). The stratigraphic resolution of siliceous plankton in the high latitudes approximates that of calcareous microorganisms in warm-water areas. True, these subdivisions should be regarded as local ones, but the time seems not far dis- tant when we shall have a Cenozoic high-latitude scale based on siliceous plankton.

The scale must be correlated both with the zonal schemes using planktonic foraminifers and nannoplankton and schemes using siliceous plankton in a moderate climatic realm. Synchronous changes among various groups of zooplankton and phytoplankton mean that the boundaries of stratigraphic subdivisions will coincide; that is, the global extent of these units (at the level of a zone or stage) will be demonstrated. Asynchronous changes among low- and high-latitude plankton mean that chronostratigraphic subdivisions will retain the rank of subglobal units.

At present we can speak only of subglobal chronostratigraphic units in the warm-water areas. But the problem has been posed, and the ways to its solution are clear. The further study of Cretaceous and Cenozoic stratigraphy at the high latitudes of the Southern and Northern Hemispheres will enable us to elucidate this most important problem of theoretical stratigraphy.

Stratigraphic studies are also closely tied with paleoclimatic problems. Planktonic microorganisms proved to be a perfect indicator of climatic changes and migrations of climatic belts. These changes show the greatest contrasts at high latitudes: hence paleotemperature studies on the Falkland Plateau and in the Argentine Basin are quite sensitive indicators. Deterioration of climatic conditions (with some fluctuations) is clearly observable throughout the Cretaceous and the Cenozoic.

In the Late Cretaceous, the temperature belts in the Southern and Northern Hemispheres were located at approximately the same paleolatitudes (Krasheninnikov and Basov, this volume). In the Neogene, the South Atlantic was much colder than the North Atlantic. Rather rich assemblages of planktonic foraminifers on the Rockall Plateau $\left(55-56^{\circ} \mathrm{N}\right.$; Krasheninnikov, 1979) have their duplicates at the latitude of the Discovery Ridge $\left(43^{\circ} \mathrm{S}\right)$. Neogene planktonic foraminifers of the Falkland Plateau and Argentine Basin $\left(51-46^{\circ} \mathrm{S}\right)$ are incommensurably more impoverished than foraminifers of the Rockall Plateau. There is no doubt that Oligocene and upper Eocene planktonic foraminifers of the Falkland Plateau are much more impoverished than those of the Rockall Plateau (Krasheninnikov, 1979).

When did this asymmetry in the location of the climatic belts appear-at the Cretaceous/Paleogene boundary or later, in Paleocene-middle Eocene time? What factors caused this asymmetry-glaciation of the Antarctic, the origination of the Gulf Stream, or more general variations in the orbital system of the Earth and Sun? Further study of the paleoclimatic peculiarities of planktonic microorganisms in the higher latitudes of the Southern and Northern Hemispheres will lead us to the solution of the most interesting and important problems of the evolution of the Cretaceous and Cenozoic climate.

\section{SYSTEMATIC PALEONTOLOGY}

This section contains information on species and subspecies of planktonic foraminifers that are of interest for their morphological, 
systematic, stratigraphic, and geographical features. Selected planktonic foraminifers are illustrated by scanning electron micrographs.

\section{Family GLOBIGERINIDAE \\ Genus GLOBIGERINA d'Orbigny, 1826 \\ Globigerina boweri Bolli \\ (Plate 1, Fig. 1-7)}

Globigerina boweri Bolli, 1957b, p. 163, pl. 36, figs. 1a-2b.

This species is characterized by three rather tightly arranged chambers in the last whorl (the last is caplike and occupies half the whorl) and by subquadrate outline and low, archlike interiomarginal aperture, rimmed by a narrow lip and extending nearly from a broadly rounded periphery to the small umbilicus. The surface is cancellate. The first of the two morphotypes of this species in our material (Figs. 1-4) has a test slightly elongated in the direction of coiling; the outline is weakly incised and the last chamber is semispherical and moderately compressed. The second morphotype (Figs. 5-7) is distinguished by a more subquadrate test with a more incised outline; the last chamber is compressed, caplike, and inflated on the umbilical side. Globigerine boweri is typical of the middle Eocene of Site 512; it is few to common and more numerous in the lower than the upper half of the section.

\section{Globigerina frontosa Subbotina}

(Plate 2, Figs. 4-7)

Globigerina frontosa Subbotina, 1953, p. 84, pl. 12, figs. 3-7.

Test of medium size, low trochospiral with a subquadrate outline and lobulate, broadly rounded periphery. Chambers inflated, compressed, wider than higher, 3-3.5 in the last whorl, rapidly enlarging in size as added. Sutures radial, depressed. Surface strongly pitted. Aperture an umbilical-extraumbilical, low, elongated slit, sometimes with a narrow unperforated lip. Umbilicus is small and narrow. Because of the extraumbilical position of the aperture, this species is referred by some authors to the genus Globorotalia, but is mostly considered as Globigerina. It is similar to $G$. boweri, differing in its more compressed chambers, in the more extraumbilical position of the aperture, which is slitlike instead of archlike as in G. boweri, and in its more incised outline. Some authors (Bandy and Kolpack, 1963; Toumarkine and Bolli, 1970) consider these species as synonyms. In our opinion these are separate taxa; $G$. boweri is an evolutionary predecessor of $G$. frontosa, which is common in the middle Eocene of Site 512 , except in the basal part of the section.

\section{Globigerina angiporoides angiporoides Hornibrook}

(Plate 3, Figs. 1-4)

Globigerina angiporoides Hornibrook, 1965, p. 834, figs. 1-2.

Specimens of this subspecies from the Leg 71 material are identical to those described by Hornibrook $(1965,1968)$ and Jenkins (1971) from the upper Eocene-lower Oligocene of New Zealand.

Test consists of four spherical chambers in the last whorl; their wall is supplied by subhexagonal pores (Fig. 2); the final chamber very often looks like an inflated bulla with a thickened lip; aperture is a narrow slit, umbilical in position. This species appears in the upper part of the middle Eocene section of Site 512, persists in the upper Eocene of Site 511, and is more common in the lower Oligocene of the Falkland Plateau (Site 511) and Argentine Basin (Site 513). It is completely absent in the upper Oligocene. Since Globigerina angiporoides angiporoides is resistant to dissolution, its disappearance can be treated as an evolutionary event.

\section{Globigerina angiporoides minima Jenkins}

(Plate 1, Figs. 8-10)

Globigerina angiporoides minima Jenkins, 1966, p. 1096, fig. 7, no. 52-7.

This species differs from Globigerina angiporoides angiporoides by its smaller size and smoother wall ornamentation. It is common in the middle Eocene of Site 512.

\section{Globigerina pseudoeocaena Subbotina}

$$
\text { (Plate 2, Figs. 1-3) }
$$

Globigerina pseudoeocaena Subbotina, 1953, p. 66, pl. 4, fig. 9; pl. 5, figs. 1-6.
This species contains four spherical chambers in the last whorl, loosely arranged and separated by deep sutures. Peripheral outline is lobulate. Umbilicus is deep. Aperture is archlike with a very narrow lip. The species is constantly present in the middle Eocene of Site 512. $G$. pseudoeocaena was first described in the U.S.S.R. (North Caucasus), where it was developed in sediments of the upper part of the lower Eocene-middle Eocene.

\section{Globigerina linaperta Finlay}

(Plate 2, Figs. 8-11)

Globigerina linaperta Finlay, 1939, p. 125, pl. 13, figs. 54-57.

In the micropaleontological literature, various species of Globigerina, originating in sediments of different ages (upper Paleocene to lower Oligocene) have been described under this name. In the Leg 71 material, typical specimens of $G$. linaperta identical to the topotypes of New Zealand have been found only in the middle Eocene sediments at Site 512. A low trochospiral test with subquadrate lobulate outline consists of 3-3.5 spherical chambers, the last one distinctly flattened (Fig. 8) and sometimes obliquely arranged (Figs. 9-10). Surface is covered by fairly coarse hexagonal pores. A low-arched aperture has a narrow, distinct lip occupying an umbilical to slightly extraumbilical position. In younger deposits of the Falkland Plateau (upper Eocene) $G$. linaperta is absent; this creates difficulties for correlation with the New Zealand Paleogene. According to Jenkins (1971), upper Eocene sediments of New Zealand are considered as falling within the $G$. linaperta Zone. Evidently, the G. linaperta range in the Falkland Plateau area is shorter, and its disappearance is due to climatic reasons.

\section{Globigerina aff. linaperta Finlay}

(Plate 3, Figs. 7-10)

This form is easily distinguished from $G$. linaperta by the rounded outline of the test, spherical, uncompressed chambers and low, slitlike aperture. Under the name of $G$. linaperta n. subsp., Jenkins and Orr (1972) described this species from the upper Eocene-lower Oligocene sediments of the tropical eastern Pacific (Leg 9). Obviously our form corresponds to $G$. linaperta in the view of Toumarkine (1978), who found this species in the Eocene-Oligocene sediments of the Walvis Ridge and the Cape Basin, Atlantic Ocean (Leg 40). Quite possibly further investigations will show that $G$. linaperta Finlay and $G$. aff. linaperta are two separate species. The latter is constantly present in the upper Eocene and lower Oligocene of the Falkland Plateau (Site 511) and in the lower Oligocene of the Argentine Basin (Site 513).

\section{Globigerina tripartita Koch}

(Plate 3, Figs. 5-6)

Globigerina bulloides tripartita Koch, 1926, p. 746, text-fig. 21.

The main characteristic features of this species are the mediumsized test with three compressed chambers in the last whorl, subquadrate and slightly lobulate outline, pitted surface, and a long, slitlike, umbilical-extraumbilical aperture with a narrow nonperforate tooth, opening in a narrow, deep umbilicus. The species is typical of the upper Eocene and Oligocene of Europe, the Caribbean, Africa, and many DSDP sites. Rare to few specimens of $G$. tripartita were found only in the upper Eocene of Site 511.

\section{Globigerina galavisi Bermudez}

(Plate 4, Figs. 1-2)

Globigerina galavisi Bermudez, 1961, p. I. 183, pl. 4, fig. 3.

Test of medium size, low trochospiral and elongated, with an oval outline and lobulate, broadly rounded periphery. Chambers inflated, subspherical, 3-3.5 in the last whorl, rapidly enlarging in size as added. Sutures radial, depressed. Wall roughly perforate; surface pitted. Aperture is a low, elongated arch with a tooth, opening in the deep, narrow umbilicus. Globigerina galavisi is widely developed in the middle Eocene to the middle Oligocene of the continents and oceans. Rare specimens of this species were found in the upper Eocene of Site 511 and lower Oligocene of Site 513.

\section{Globigerina praebulloides Blow}

(Plate 4, Figs. 3-6)

Globigerina praebulloides Blow, 1959, p. 180, pl. 8, fig. 47.

Test low trochospiral. Chambers subspherical, $3.5-4$ in the last whorl, enlarging rapidly in size. Sutures distinct, slightly curved on 
spiral side and radial on umbilical side, strongly depressed, forming lobulate periphery. Outline slightly elongated, surface distinctly pitted. Aperture is a medium-sized arch opening in the narrow umbilicus and bordered by distinct rim (Figs. 4-5). The species is common in the upper Eocene-upper Miocene of many areas of the world. Rarely present in the lower Oligocene of Sites 511 and 513.

\section{Globigerina prasaepis Blow}

(Plate 4, Figs. 7-12)

Globigerina prasaepis Blow, 1969, p. 382, pl. 10, fig. 13; pl. 18, figs. 3-7.

This species is characterized by an inflated, relatively high trochospiral test with 3.5-4 tightly coiled chambers in the last whorl, radial depressed sutures and archlike umbilical aperture with a very narrow indistinct lip. Widely distributed in the uppermost Eocene-Oligocene of many localities, and rare to few in the lower Oligocene sediments of Sites 511 and 513 .

\section{Globigerina officinalis Subbotina}

(Plate 5, Figs. 1-3)

Globigerina officinalis Subbotina, 1953, p. 78, pl. II, figs. 1, 2, and 5.

This species is readily distinguished by its small test with convex spiral side, moderately convex umbilical side, and four subglobular chambers in the last whorl, located crosslike, with a high, arched aperture opening in the narrow, deep umbilicus. Widely distributed in the Oligocene sediments throughout the world and present in the lower part of the Oligocene at Site 511 (usually rare to few and common in separate samples)

\section{Globigerina labiacrassata Jenkins}

(Plate 5, Figs. 4-7)

Globigerina labiacrassata Jenkins, 1966, p. 1102, fig. 8, nos. 64-71.

Test low trochospiral, with subquadrilobate (Figs. 4-5) or quadrilobate (Figs. 6-7) outline and rounded periphery. The last whorl contains 3.5-4 tightly coiled chambers with coarsely perforate wall. Aperture is a high arch, umbilical, with a thick rim. Morphological features of this species are identical to those of New Zealand specimens. Rare in the lower Oligocene of Site 511 and the upper Oligocene of Site 513.

\section{Globigerina senilis Bandy \\ (Plate 5, Figs. 8-11)}

Globigerina ouachitaensis senilis Bandy, 1949, p. 121, pl. 22, fig. 5.

Medium-sized test, tightly coiled, with four chambers set crosslike in the last whorl. Aperture is a high or normal arch with a very narrow rim, umbilical. A characteristic feature of this species is the cancellate surface of the umbilical side (Figs. 9-10). Narrow sharp divides form a polygonal net; the central deep part of every polygonal cell is occupied by a tiny pore. Rare to few in the lower Oligocene of Sites 511 and 513

\section{Globigerina ouachitaensis Howe and Wallace}

(Plate 6, Figs. 1-2)

Globigerina ouachitaensis Howe and Wallace, 1932, p. 74, pl. 10, fig. 7.

A small test of this species consists of 4-4.5 spherical chambers separated by deep sutures giving strongly lobulate periphery. Umbilical, high-arched aperture bordered by a rim. Widely developed in the upper Eocene-Oligocene of many localities. Rarely present in the lower Oligocene of Sites 511 and 513, being common in separate samples.

\section{Globigerina woodi woodi Jenkins}

(Plate 11, Figs. 1-4)

Globigerina woodi woodi Jenkins, 1971, p. 159, pl. 18, figs. 548-550.

Four-chambered inflated test with roughly cancellate surface and lobulate outline. Umbilicus wide and deep; long, high, archlike aperture opens to umbilicus without marginal rim. South Atlantic specimens greatly resemble New Zealand forms. This subspecies is represented by few to rare specimens in the lower Miocene sediments of Site 513, Argentine Basin.

\section{Globigerina woodi connecta Jenkins}

(Plate 11, Figs. 5-7)

Globigerina woodi connecta Jenkins, 1964, p. 72, text-fig. 1a-c.

This subspecies differs from $G$. woodi woodi by its test, which is more elongated in the direction of coiling; it has fewer chambers in the last whorl (3-3.33) and a narrow slitlike aperture. The surface preserves a cancellate pattern. Rare to few specimens in the lower Miocene of Site 513 .

\section{Globigerina bulloides bulloides d'Orbigny}

(Plate 11, Figs. 8-10)

Globigerina bulloides bulloides d'Orbigny, 1826, p. 277.

Typical specimens of this universal species in the area of the Falkland Plateau appear in the upper Miocene, Site 512. Common to the Pliocene-Quaternary sediments of Sites 511-514.

\section{Globigerina bulloides quadrilatera Galloway and Wissler}

$$
\text { (Plate 12, Figs. 4-9) }
$$

Globigerina quadrilatera Galloway and Wissler, 1927, p. 44, pl. 7, fig. 11.

This variety differs from $G$. bulloides bulloides in its subquadrate outline of a four-chambered test with a big umbilical aperture. Rare to few specimens in the Pliocene-Quaternary sediments of Sites 512514

\section{Globigerina bulloides decoraperta Takayanagi and Saito}

(Plate 12, Figs. 10-13)

Globigerina decoraperta Takayanagi and Saito, 1962, p. 85, pl. 28, fig. 10.

This subspecies is distinguished from $G$. bulloides bulloides by the thickened narrow rim of the aperture. Few to common in the middle to upper Miocene of Site 512 .

\section{Globigerina pachyderma (Ehrenberg)}

(Plate 12, Figs. 1-3)

Asterospira pachyderma Ehrenberg, 1861, p. 303.

Forms similar to $G$. pachyderma appear in the upper Miocene of Site 512. Common to Pliocene-Quaternary sediments of Sites 511514.

\section{Genus GLOBIGERINITA Brönnimann, 1951 Globigerinita pera (Todd) \\ (Plate 6, Figs. 3-4)}

Globigerina pera Todd, 1957 , p. 301, pl. 70, figs. 10-11.

Subspherical test has 3.5 tightly coiled chambers with a hexagonal net on the surface. Bulla is well defined, inflated, with a single infralaminal aperture. Rare specimens in the upper Eocene of Site 511.

\section{Globigerinita martini Blow and Banner}

(Plate 6, Figs. 5-8)

Globigerinita martini Blow and Banner, 1962, p. 110, pl. 4, figs. 0, $\mathrm{V}-\mathrm{X}$.

This very distinctive species has a small inflated test composed of closely arranged globular chambers with four of them in the last whorl, oval outline, depressed sutures, and small deep umbilicus covered by strongly pronounced bulla. Seeming to co-occur in the Leg 71 material are two varieties of this species, differing by inflation of chambers and bülla (Globigerinita martini and G. martini scandretti). The species is regularly present in the upper Eocene-lower Oligocene of Site 511 and in the lower Oligocene of Hole 513A and is very rare to few in number.

\section{Globigerinita unicava (Bolli, Loeblich, and Tappan)}

(Plate 6, Figs. 9-10)

Catapsydrax unicavus Bolli, Loeblich, and Tappan, 1957, p. 37, pl. 7, fig. $9 \mathrm{a}-\mathrm{c}$.

This species, with a small, compactly built test, is constantly present in the middle Eocene of Site 512 and in the lower Oligocene of 
Sites 511 and 513 and is usually rare to few. It is represented by two varieties, G. unicava unicava and $G$. unicava primitiva.

\section{Globigerinita glutinata (Egger)}

$$
\text { (Plate 13, Figs. 1-2) }
$$

Globigerina glutinata Egger, 1893, p. 371, pl. 13, figs. 19-21.

Rare but typical specimens of this universal species with thin, inflated, and elongated bulla furnished with 2-3 infralaminal apertures were found in the Quaternary sediments of Site 511.

\section{Globigerinita dissimilis (Cushman and Bermudez)}

(Plate 13, Figs. 3-5)

Globigerina dissimilis Cushman and Bermudez, 1937, p. 37, pl. 7, fig. 9.

Rare specimens of this species with 3-3.5 inflated chambers in the last whorl and bulla with 3-4 infralaminal accessory apertures were encountered in the lower Miocene of Hole 513A. They are characterized by a strongly etched surface.

\section{Globigerinita uvula (Ehrenberg)}

(Plate 13, Figs. 6-8)

Pylodexia uvula Ehrenberg, 1861, p. 308.

High-conical test consists of 3-4 whorls composed of loosely united spherical chambers; bulla is thin, inflated, and small, with a few rounded infralaminal apertures. In the area of the Falkland Plateau (Sites 511 and 512) this species is developed in sediments of the middle Miocene to Quaternary, being rare to few and common in some Quaternary samples; rare specimens in the Pliocene-Quaternary of the Argentine Basin (Sites 513 and 514).

\section{Genus TURBOROTALITA Blow and Banner, 1962 \\ Turborotalita aff. iota Parker \\ (Plate 13, Figs. 9-10)}

The modified bullalike last chamber covers the umbilical area on the ventral side; three infralaminal apertures are in line with intercameral sutures. Rare specimens in the Quaternary of the Falkland Plateau (Site 511). Limited material does not allow us to estimate all morphological features of this species.

\section{Genus GLOBIGERAPSIS Bolli, Loeblich, and Tappan, 1957 Globigerapsis index (Finlay)}

(Plate 7, Figs. 1-5)

Globigerinoides index Finlay, 1939, p. 125, pl. 14, figs. 85-88.

The species is distinguished by a subglobular test of which the last chamber occupies nearly one half, and deep, incised, intercameral sutures. The primary umbilical aperture is a long, high-arched opening with a fimbriate rim. Most specimens in our material contain only this umbilical aperture. Some specimens (evidently adult) have, at the base of the final chamber, one supplementary aperture of the same shape as the umbilical aperture but smaller. Rare to few specimens in the middle Eocene (Site 512) and upper Eocene (Site 511) of the Falkland Plateau.

\section{Globigerapsis aff. tropicalis Blow and Banner} (Plate 7, Fig. 6)

To this taxon we attribute spherical tests with tightly arranged chambers and rounded supplementary apertures at the base of the last chamber. They are present sporadically in the upper Eocene of Site 511 .

\section{Genus GLOBOROTALOIDES Bolli, 1957 \\ Globorotaloides turgidus (Finlay)}

(Plate 7, Figs. 7-9)

Globigerina linaperta Finlay var. turgida Finlay, 1939, p. 125.

A biconvex test with quadrilobate outline contains four oval to spherical chambers in the last whorl. Surface is covered by pentagonal or hexagonal pits, especially rough on the umbilical side. The last chamber forms a bullalike protrusion which covers the umbilical area completely. The infralaminal aperture opens to the antepenultimate chamber. Rare specimens of this species were found in the middle Eocene of Site 512. Their morphology is identical to that of New Zealand forms.

\section{Globorotaloides suteri Boll}

(Plate 8, Fig. 1-5)

Globorotaloides suteri Bolli, 1957b, p. 117, pl. 27, figs. 9a-13b.

Test of medium size, low trochospiral, biconvex, spiral side more convex than umbilical, with lobulate outline. Chambers spherical, 4-5 in the last whorl, enlarging rather rapidly in size as added. Surface perforate, cancellate. Sutures radial, depressed. In mature specimens umbilicus is partly or completely covered by bulla. Aperture a slit or low arch; specimens with bullas have infralaminal apertures.

Constantly present in the middle Eocene of Site 512, upper Eocene-Oligocene of Site 511, and Oligocene of Site 513.

\section{Genus ACARININA Subbotina, 1953 \\ Acarinina pseudotopilensis Subbotina}

(Plate 8, Fig. 6)

Acarinina pseudotopilensis Subbotina, 1953, p. 227, pl. 21, figs. 8-9; pl. 22, figs. 1-3.

Test biconvex, with inflated umbilical side. Chambers triangular in shape, 4 in the last whorl, rapidly enlarging in size as added, the last chamber comprising about one-third of the test. The outline is trapezoidal lobulate. Umbilical side is subtruncate, the peripheral margin not angular. Sutures distinct, radial, depressed. Surface hispid, covered by small spines. Aperture a low slit, interiomarginal, extraumbili$\mathrm{cal}$, opening in small umbilicus. Constantly present though rare in the lower part of the middle Eocene of Site 512.

Acarinina sp.

(Plate 8, Figs. 7-10)

These low trochospiral Acarinina with 5-6 spherical chambers in the last whorl and a hispid surface are constantly present, rare to few, in the middle Eocene sediments of Site 512.

\section{Acarinina bullbrooki (Bolli)}

(Plate 9, Figs. 1-3)

Globorotalia bullbrooki Bolli, 1957b, p. 167, pl. 38, figs. 4a-5c.

Test low trochospiral with nearly flat spiral side and strongly convex umbilical side. Chambers subangular, inflated, four in the last whorl, rapidly enlarging in size. Sutures distinct, oblique on spiral side and radial on umbilical side. Periphery lobulate, subangular. Surface covered with short spines. Aperture a low umbilical-extraumbilical arch extending from the periphery to the deep, narrow umbilicus. Sporadically present in the lower middle Eocene of Site 512 .

\section{Genus PSEUDOGLOBOQUADRINA Jenkins, 1965 Pseudogloboquadrina primitiva (Finlay) \\ (Plate 9, Figs. 4-7)}

Globoquadrina primitiva Finlay, 1947, p. 291, pl. 8, figs. 129-134.

Test low trochospiral, with a subquadrate outline, spiral side flattened, umbilical side strongly convex and truncated. The last whorl contains 3.5-4 chambers, compressed laterally, with flattened sides, gradually enlarging in size. Surface roughly perforated, covered by pustules. In the umbilical area the latter yield irregular rugosites (Fig. 5). Low, elongated, slitlike aperture opens in a small, deep umbilicus. The apertural face is steep, smooth, with a thickened lip (Fig. 6). This species is developed throughout the middle Eocene of Site 512; it is usually rare to few, becoming common in the middle part of the stratigraphic interval.

Morphological features of $P$. primitiva specimens from the Falkland Plateau and New Zealand areas are very similar. We cannot exclude the possibility that this species is endemic, being characteristic only of the Eocene of the Southern Hemisphere. Planktonic foraminifers described from the upper Paleocene-Eocene of the Northern Hemisphere under the names Globorotalia primitiva or Acarinina primitiva should be attributed to any species of Acarinina. 


\section{Genus PSEUDOHASTIGERINA Banner and Blow, 1959}

\section{Pseudohastigerina micra (Cole)}

(Plate 9, Figs. 8-10)

Nonion micrus Cole, 1927, p. 22, pl. 5, fig. 12.

Test small, planispiral, biumbilicate, laterally compressed. Chambers inflated, subglobular, six in the last whorl, enlarging rapidly in size as added. Sutures curved, depressed. Periphery lobulate, rounded, with a smooth surface; wall finely perforate. Aperture a low, interiomarginal, equatorial arch bordered by a distinctive lip. The species is constantly present, few to common, throughout the middle Eocene of Site 512; in the upper and lower Eocene of the Falkland Plateau, $P$. micra has not been discovered.

\section{Genus CHILOGUEMBELINA Loeblich and Tappan, 1956 Chiloguembelina cubensis (Palmer) (Plate 10, Figs. 1-2)}

Guembelina cubensis Palmer, 1934, p. 74, figs. 1-6.

This geographically widely distributed species is constantly present in sediments of the middle Eocene (Site 512), upper Eocene (Site 511), and lower Oligocene (Sites 511 and 513), being rare to few and common in separate samples.

\section{Genus HANTKENINA Cushman, 1925}

Hantkenina sp.

(Plate 10, Fig. 3)

A single specimen of Hantkenina from the middle Eocene of Site 512 confirms the cold-water character of this microfauna. It belongs either to $H$. alabamensis (with straight spines) or to $H$. australis (with recurved spines). Unfortunately, the spines of this specimen are bro$\mathrm{ken}$, and species determination is impossible.

\section{Genus GLOBOROTALIA Cushman, 1927 Globorotalia collactea Finlay \\ (Plate 10, Figs. 4-5)}

Globorotalia collactea Finlay, 1939, p. 37, pl. 29, figs. 164-165.

Test low trochospiral with nearly flat spiral side and convex umbilical side. Chambers inflated, six in the last whorl, enlarging rather gradually in size as added. Sutures distinct, radial, depressed. The outline slightly elongated, periphery lobulate, broadly rounded. Aperture low, interiormarginal umbilical, archlike, bordered by a narrow lip. Rare specimens of $G$. collactea in the middle Eocene of Site 512.

The position of the aperture has given some authors (Brönnimann, 1952) reason to assign this species to the genus Globigerina, but the tendency to take the extraumbilical position counters this assumption.

\section{Globorotalia gemma Jenkins}

(Plate 10, Figs. 6-9)

Globorotalia gemma Jenkins, 1966, pp. 1115-1116, fig. 11, nos. 97-103.

Test very small, low trochospiral, flattened, with lobulate periphery. The last whorl contains five globular chambers increasing gradually in size. Surface smooth, finally perforated, with tiny pustules. Umbilicus small. Aperture slitlike, interiomarginal, umbilical-extraumbilical. Our specimens are identical to those described and illustrated by Jenkins (1971) from different localities of New Zealand. This species is constantly present throughout the uppermost Eocene and lower Oligocene of Sites 511 and 513.

Under the name Globigerina postcretacea Mjatliuk, 1950, this species was described for the first time from synchronous sediments of the Carpathians and Caucasus (U.S.S.R.). Because of the rules governing the formal nomenclature its proper name should be treated as Globorotalia gemma Jenkins, 1966.

\section{Globorotalia munda Jenkins}

(Plate 10, Figs. 10-12)

Globorotalia munda Jenkins, 1966, p. 1121, fig. 14, nos. 126-133; fig. 13 , nos. 152-166.

This species differs from $G$. gemma by its four-chambered test (in the last whorl) and subquadrate outline. The wall is the same, finely perforate, smooth, with minute pustules (Figs. 10 and 12). Some spe- cimens of the similar general form possess, nevertheless, a cancellate umbilical side (Fig. 11) and obviously belong to any other species of Globorotalia. Constantly, present, rare to few, in the uppermost Eocene-lower Oligocene of Sites 511 and 513.

\section{Globorotalia continuosa Blow} (Plate 14, Figs. 1-4)

Globorotalia continuosa Blow, 1959, p. 218, pl. 19, fig. 125a-c.

A small test with subquadrate outline; the last whorl consists of four tightly coiled chambers. Spiral and umbilical sides are covered by a rough hexagonal net, its surface cancellated. Arched aperture with very thick rim. Rare to few specimens in the middle Miocene of Site 512 .

\section{Globorotalia acostaensis Blow}

(Plate 14, Figs. 5-7)

Globorotalia acostaensis Blow, 1959, p. 208, pl. 17, figs. 106-107.

Test low trochospiral, biconvex. Chambers inflated, usually five in the last whorl, enlarging gradually in size as added. The last chamber is sometimes reduced in size. Sutures distinct, radial, depressed. Outline circular, lobulate; periphery broadly rounded; surface distinctly pitted. Aperture extraumbilical-umbilical, a low arch bordered by a thin rim. Rarely present in the upper Miocene of Site 512.

\section{Globorotalia puncticulata (Deshayes)}

(Plate 14, Figs. 8-11)

Globigerina puncticulata Deshayes, 1832 , p. 170

This species differs from Globigerina inflata by the subquadrate outline of the test, numerous pustules on the spiral and umbilical sides (they are especially common in the umbilical area) and extraumbilical aperture. Rare to few specimens in the Pliocene sediments of the Argentine Basin (Sites 513 and 514).

\section{Globorotalia inflata (d'Orbigny)}

(Plate 15, Figs. 1-4)

Globigerina inflata d'Orbigny, 1839, p. 134, pl. 2, figs. 7-9.

This easily recognized and widely distributed species is common in the Pliocene-Quaternary sediments of the Falkland Plateau and Argentine Basin (Sites 511-514).

\section{Globorotalia scitula (Brady) \\ (Plate 15, Figs. 5-8)}

Pulvinulina scitula Brady, 1882, p. 716

Test trochospiral, nearly equally biconvex. chambers strongly compressed, 4-5 in the last whorl, rapidly enlarging in size. Sutures distinct, strongly curved on the spiral side, slightly curved on the umbilical side. Outline rounded, periphery lobulate, angular; surface smooth, perforate, with nonperforate narrow band along the peripheral margin. Aperture a low umbilical-extraumbilical slit extending nearly from periphery to narrow, shallow umbilicus. It is common in the middle Miocene of Site 512 and rare to few in the Pliocene-Quaternary of Sites 511 and 514 .

\section{Globorotalia truncatulinoides (d'Orbigny)} (Plate 15, Figs. 9-11)

Rotalia truncatulinoides d'Orbigny, 1839, p. 137, pl. 2, figs. 25-27.

The specimens differ from the typical $G$. truncatulinoides in having a lower conical test, distinctly convex spiral side and less pronounced peripheral keel. We agree with Herb (1968), who considered similar forms from the Recent sediments of adjacent areas as a coldwater variety. The species is encountered commonly in the Quaternary sediments of Sites 511-514.

\section{ACKNOWLEDGMENTS}

This study was made possible owing to the kind invitation of the Deep Sea Drilling Project to take part in Leg 71. Dr. M. Y. Serova and Dr. T. P. Bondareva, Geological Institute of the U.S.S.R. Academy of Sciences, Moscow, agreed to review the paper and made many valuable suggestions. The micrographs were taken by M. I. Ivanov and L. Y. Davydova (Institute of the Lithosphere of the U.S.S.R. Academy of Sciences, Moscow). We express our sincere gratitude to all these persons. 


\section{REFERENCES}

Bandy, O. L., 1949. Eocene and Oligocene Foraminifera from Little Stave Greek, Clarke County, Alabama. Bull. Am. Paleontol. 32(no. 131).

Bandy, O., and Kolpack, R., 1963. Foraminiferal and sedimentological trends in the Tertiary section of Tecolote Tunnel, California. Micropaleontology, 9(no. 2).

Barker, P. F., Dalziel, I. W. D., et al., 1977. Init. Repts. DSDP, 36: Washington (U.S. Government Printing Office).

Berggren, W. A., 1972. Late Pliocene-Pleistocene glaciation. In Laughton, A. S., Berggren, W. A, et al., Init. Repts. DSDP, 12: Washington (U.S. Govt. Printing Office), 953-964.

Bermudez, P. J., 1961. Contribución al estudio de las Globigerinidea de la region Caribe-Antilana (Paleoceno-Reciente). 3 Congr. Geol. Venez., Bol. Geol. Mem., vol. 3, Spec. Publ. 3.

Bertels, A., 1964. Micropaleontología del Paleoceno de general Roca (Provincia de Río Negro). Rev. Mus. La Plata, N. Ser., paleontol., 4(no. 23).

Blow, W. H., 1959. Age, correlation and biostratigraphy of the upper Tocuyo (San Lorenzo) and Pozón formations, eastern Falcón, Venezuela. Bull. Am. Paleontol., 39(no. 178).

1969. Late middle Eocene to Recent planktonic foraminiferal biostratigraphy. Proc. I Intern. Conf. Planktonic Microfossils: Leiden (E. Y. Brill).

Blow, W. H., and Banner, F. T., 1962. The mid-Tertiary (upper Eocene to Aquitanian) Globigerinacea. In. Eames, F. E., et al. (Eds.), Fundamentals of Mid-Tertiary Stratigraphic Correlation. Cambridge, England (Cambridge University Press).

Bolli, H., 1957a. The genera Globigerina and Globorotalia in the Paleocene-lower Eocene Lizard Springs formation of Trinidad, B.W.I. U.S. Nat. Mus. Bull., No. 215. 1957b. Planktonic Foraminifera from the Eocene Navet and San Fernando formations of Trinidad, B.W.I. U.S. Nat, Mus. Bull., No. 215.

1957c. Planktonic foraminifera from the Oligocene-Miocene Cipero and Lengua Formations of Trinidad, B.W.I. U.S. Nat. Mus. Bull., No. 215.

1959. Planktonic foraminifera as index fossils in Trinidad, West Indies, and their value for world-wide stratigraphic correlation. Eclogae Geol. Helv., 52(no. 2).

Bolli, H. M., Loeblich, A. R., and Tappan H., 1957. Planktonic foraminiferal families Hantkeninidae, Orbulinidae, Globorotaliidae and Globotruncanidae. U.S. Nat. Mus. Bull., No. 215.

Brady, H. B., 1884. Report on the Scientific Results of the Voyage Of H.M.S. Challenger during the Years 1873-1876. Zoology (Vol. 9). Report on the Foraminifera.

Brönnimann, P., 1952. Trinidad Paleocene and lower Eocene Globigerinidae. Bull. Am. Paleontol., 34(no. 143).

Busen, K. E., and Wise, S. W., 1977. Silicoflagellate stratigraphy, Deep Sea Drilling Project, Leg 36. In Barker, P. F., Dalziel, I. W. D, et al., Init. Repts. DSDP, 36: Washington U.S. Govt. Printing Office), 697-743.

Ciesielski, P. F., and Weaver, F. M., 1974. Early Pliocene climatic change in the Antarctic seas. Geology, 2(no. 10):511-515.

Cole, W. S., 1927. A foraminiferal fauna from the Guayabal Formation, Mexico. Bull. Am. Paleontol., Vol. 14.

Curray, R. R., 1966. Glaciation about 3,000,000 years ago in the Sierra Nevada. Science, 154:770-771.

Cushman, J. A., and Bermudez, P. J., 1937. Further new species of Foraminifera from the Eocene of Cuba. Contr. Cushman Lab. Foram. Res., 13(pt. 1).

Deshayes, G. P., 1832. Encyclopedie Methodique. Hist. Nat. des Vers: Paris (Mme. V. Agasse), Vol. 2(no. 2).

Devereux, I., 1967. Oxygen isotope paleotemperature measurements of New Zealand Tertiary fossils. N.Z. J. Sci., 10:988-1011.

1968. Oxygen isotope paleotemperatures from the Tertiary of New Zealand. Tuatura, 16:41-44.

d'Orbigny, A. D., 1826. Tableau methodique de la classe des Céphalopodes. Ann. Sci. Nat. Paris, Ser. I (Vol. 7).

1839. Foraminiferes. In de la Sagra, R., (Ed.), Histoire Physique, Politique et Naturelle de l'ile de Cuba: Paris (Bertrand).

Egger, J. G., 1893. Foraminiferen aus Meeresgrundproben, gelothet von 1874 bis 1876 von S. M. Sch. Gazelle. K. Bayer. Akad. Wiss., München, Math.-Phys. Kl., Abh., 18(pt. 2).
Ehrenberg, C. G., 1861. Ueber die Tiefgrund-Verhältnisse des Ozeans am Eingange der Davisstrasse und bei Island. K. Preuss. Akad. Wiss. Berlin. Monatsber..

Finlay, H. J., 1939. New Zealand foraminifera, key species in stratigraphy. Trans. R. Soc. N.Z., 69(pt. 1).

1947. New Zealand foraminifera, key species in stratigraphy. N.Z.J. Sci. Tech., 28(no. 5, sec. B).

Galloway, J. J., and Wissler, S. G., 1927. Pleistocene foraminifera from the Lomita Quarry, Palos Verdes Hills, California. J. Paleontol., 1.

Geiger, M., 1962. Planktonic foraminiferal zones in the upper Tertiary of Taranaki, New Zealand. N.Z.J. Geol. Geophys., 5(no. 2).

Gombos, A. M., Jr., 1977. Paleogene and Neogene diatoms from the Falkland Plateau and Malvinas Outer Basin: Leg 36, Deep Sea Drilling Project. In Barker, P. F., Dalziel, I. W. D., et al., Init. Repts. DSDP, 36: Washington (U.S. Govt. Printing Office), 575-695.

Hayes, D. E., Frakes, L. A., et al., 1975. Init. Repts. DSDP, 28: Washington (U.S. Govt. Printing Office).

Herb, R., 1968. Recent planktonic foraminifera from sediments of the Drake Passage, Southern Ocean. Eclogae Geol. Helv., 61(2): 467-480.

Hornibrook, N. B., 1958. New Zealand Upper Cretaceous and Tertiary foraminiferal zones and some overseas correlations. Micropaleontology, 4(1):25-38.

1961. Tertiary foraminifera from Oamaru district (N.Z.). N.Z. Geol. Surv. Paleontol. Bull., No. 34(pt. 1).

1965. Globigerina angiporoides n. sp. from the upper Eocene-lower Oligocene of New Zealand and the status of Globigerina angipora Stache, 1965. N.Z.J. Geol. Geophys., 8(no. 5).

1966. The Orbulina bioseries in the Glidfen section, New Zealand. Proc. III Sess. Commiss. Mediterr. Neogene Stratigr.: Leiden (E.Y. Brill).

1967. New Zealand Microfossils. N.Z. Dept. Sci. Indust. Res. Inform. Ser., No. 62.

1968. Handbook of New Zealand Microfossils. N.Z. Dept. Sci. Indust. Res. Inform. Ser., No. 62.

Howe, H. V., and Wallace, W. E., 1932. Foraminifera of the Jackson Eocene at Danville Landing on the Ouachita, Catahoula Parish, Louisiana. Louisiana Dept. Conserv. Geol. Bull. 2.

Jenkins, D. G., 1964. A new planktonic foraminiferal subspecies from the Australian lower Miocene. Micropaleontology, 10(no. 1). 1965a. The Genus Hantkenina in New Zealand. N.Z.J. Geol. Geophys., 8(3):518-526.

$1965 \mathrm{~b}$. The origin of the species Globigerinoides trilobus (Reuss) in New Zealand. Contr. Cushman Found. Foram. Res., 16(pt. 3):116-120.

$1965 \mathrm{c}$. Planktonic foraminifera and Tertiary intercontinental correlations. Micropaleontology, 11(no. 3):265-277.

1966. Planktonic foraminiferal zones and new taxa from the Danian to Lower Miocene of New Zealand. N.Z.J. Geol. Geophys., 8(6):1088-1126.

1967. Planktonic foraminiferal zones and new taxa from the lower Miocene to the Pleistocene of New Zealand. N.Z.J. Geol. Geophys., 10(4):1064-1078.

1970. Foraminiferida and New Zealand Tertiary biostratigraphy. Rev. Espan. Micropaleontol., 2(no. 1).

1971. New Zealand Cenozoic Planktonic Foraminifera. N.Z. Geol. Surv. Paleontol. Bull., Vol. 42.

1973. Diversity changes in the New Zealand Cenozoic planktonic foraminifera. J. Foram. Res., 3:78-88.

1975. Cenozoic planktonic foraminiferal biostratigraphy of the southwestern Pacific and Tasman Sea, DSDP Leg 29. In Kennett, J. P., Houtz, R. E., et al., Init. Repts. DSDP, 29: Washington (U.S. Govt. Printing Office), 449-467.

1978. Neogene planktonic foraminifers from DSDP Leg 40 Sites 360 and 362 in the southeastern Atlantic. In Bolli, H. M., Ryan, W. B. F., et al., Init. Repts. DSDP, 40: Washington (U.S. Govt. Printing Office), 723-729.

Jenkins, D. G., and Orr, W. N., 1972. Planktonic foraminiferal biostratigraphy of the eastern equatorial Pacific, DSDP Leg 9. In Hays, J. D., et al., Init. Repts. DSDP, 9: Washington (U.S. Govt. Printing Office), 1059-1205.

Kaneps, A. G., 1975. Cenozoic planktonic foraminifera from Antarctic deep-sea sediments, Leg 28, DSDP. In Hayes, D. E., Frakes, L. 
A., et al., Init. Repts. DSDP, 28: Washington (U.S. Govt. Printing Office), 573-583.

Kennett, J. P., 1967. New foraminifera from the upper Miocene and lower Pliocene of New Zealand. N.Z.J. Geol. Geophys. 10, (no. 4).

1968. Paleo-oceanographic aspects of the foraminiferal zonation in the upper Miocene-lower Pliocene of New Zealand. Giorn. Geol., Ser. 2, 35(3).

1975. Neogene planktonic foraminiferal stratigraphy in Deep Sea Drilling Sites, southeast Indian Ocean. In Hayes, D. E., Frakes, L. A., et al., Init. Repts. DSDP, 28: Washington (U.S. Govt. Printing Office), 705-708.

Kennett J. P., Houtz, R. E., et al., 1975. Init. Repts. DSDP, 29: Washington (U.S. Govt. Printing Office).

Kennett, J. P., and Vella, P., 1975. Late Cenozoic planktonic foraminifera and paleoceanography at DSDP Site 284 in the cool subtropical South Pacific. In Kennett J. P., Houtz, R. E., et al., Init. Repts. DSDP, 29: Washington (U.S. Govt. Printing Office), 769-799.

Koch, R., 1926. Mitteltertiäre Foraminiferen aus Bulongan, Öst-Borneo. Eclogae Geol. Helv., 19:

Krasheninnikov, V. A., 1979. Stratigraphy and planktonic foraminifers of Cenozoic deposits of the Bay of Biscay and Rockall Plateau, DSDP Leg 48. In Montadert, L., Roberts, D. G., et al., Init. Repts. DSDP, 48: Washington (U.S. Govt. Printing Office), 431-450.

Krasheninnikov, V. A., and Muzylöv, N. G., 1975. Relationship between the zonal scales based on planktonic foraminifers and nannoplankton in Paleogene sections of the North Caucasus. Quest. micropaleontol., 18:212-224. (In Russian)

Ludwig, W. J., Krasheninnikov, V. A., et al., 1980. Tertiary and Cretaceous paleoenvironments in the southwest Atlantic Ocean: Preliminary results of the Deep Sea Drilling Project, Leg 71. Geol. Soc. Am. Bull., Pt. I, 91:655-664.

Martin, L. I., 1943. Eocene Foraminifera from the type Lodo Formation, Fresno County, California. Stanford Univ. Publ. Geol. Sci., 3(no. 3).

Mjatliuk, E. V., 1950. Stratigraphy of flysch sediments of the North Carpathians in the light of foraminiferal fauna. Proc. VNIGRI, N. SER., 51:225-287.

Palmer, D. K., 1934. Some Large Fossil Foraminifera from Cuba. Soc. Cub. Hist. Nat. Mem. 8.

Poore, R. L., 1979. Oligocene through Quaternary planktonic foraminiferal biostratigraphy of the North Atlantic: DSDP Leg 49. In
Luyendyk, B. P., Cann, J. R., et al., Init. Repts. DSDP, 49: Washington (U.S. Govt. Printing Office), 447-517.

Rögl, F., 1976. Late Cretaceous to Pleistocene foraminifera from the southeast Pacific basin, DSDP Leg 35. In Hollister, C. D., Craddock, C., et al., Init. Repts. DSDP, 35: Washington (U.S. Govt. Printing Office), 539-555.

Shackleton, N. J., and Kennett, J. P., 1975. Paleotemperature history of the Cenozoic and the initiation of Antarctic glaciation: Oxygen and carbon isotope analyses in DSDP Sites 277, 279, and 281. In Kennett, J. P., Houtz, R. E., et al., Init. Repts. DSDP, 29: Washington (U.S. Govt. Printing Office), 743-755.

Sliter, W. V., 1977. Cretaceous foraminifers from the southwestern Atlantic Ocean, Leg 36, Deep Sea Drilling Project. In Barker, P. F., Dalziel, I. W. D., et al., Init. Repts. DSDP, 36: Washington (U.S. Govt. Printing Office), 519-573.

Subbotina, N. N., 1953. Globigerinidae, Hantkeninidae, and Globorotaliidae. Fossil foraminifera of the USSR. VNIGRI, Trudy, $N$. Ser., No. 76.

Takayanagi, Y., and Saito, T. 1962. Planktonic Foraminifera from the Nobori Formation, Shikoku, Japan. Tohoku Univ. Sci. Repts., 2 Ser. (Geol.), Spec. Vol. 5.

Tjalsma, R. C., 1977. Cenozoic foraminifera from the South Atlantic, DSDP Leg 36. In Barker, P. F., Dalziel, I. W. D., et al., Init. Repts. DSDP, 36: Washington (U.S. Govt. Printing Office), 493-517.

Todd, R., 1957. Geology of Saipan, Mariana Islands: Smaller Foraminifera. U.S. Geol. Surv. Prof. Paper 280-H.

Todd, R., and Kniker, H., 1952. An Eocene Foraminiferal Fauna from the Agua Fresca Shale of Magallanes Province, Southernmost Chile. Cushman Lab. Foram. Res. Spec. Publ. No. 1.

Toumarkine, M., 1978. Planktonic foraminiferal biostratigraphy of the Paleogene of Sites 360 to 364 and the Neogene of Sites 362A, 363, and 364 Leg 40. In Bolli, H. M., Ryan, W. B. F., et al., Init. Repts. DSDP, 40: Washington (U.S. Govt. Printing Office), 679-721.

Toumarkine, M., and Bolli, H. M., 1970. Evolution de Globorotalia cerroazulensis (Cole) dans l'éocène moyen et supérieur de Possagno (Italie). Rev. Micropaleontol., 13(no. 3).

Vail, P. R., and Hardenbol, J., 1979. Sea level changes during the Tertiary. Oceanus, 22(no, 3):73-79.

Wise, S. W., and Wind, F. H., 1977. Mesozoic and Cenozoic calcareous nannofossils recovered by DSDP Leg 36 drilling on the Falkland Plateau, Southwest Atlantic sector of the Southern Ocean. In Barker, P. F., Dalziel, I. W. D., et al., Init. Repts. DSDP, 36: Washington (U.S. Govt. Printing Office), 269-491. 


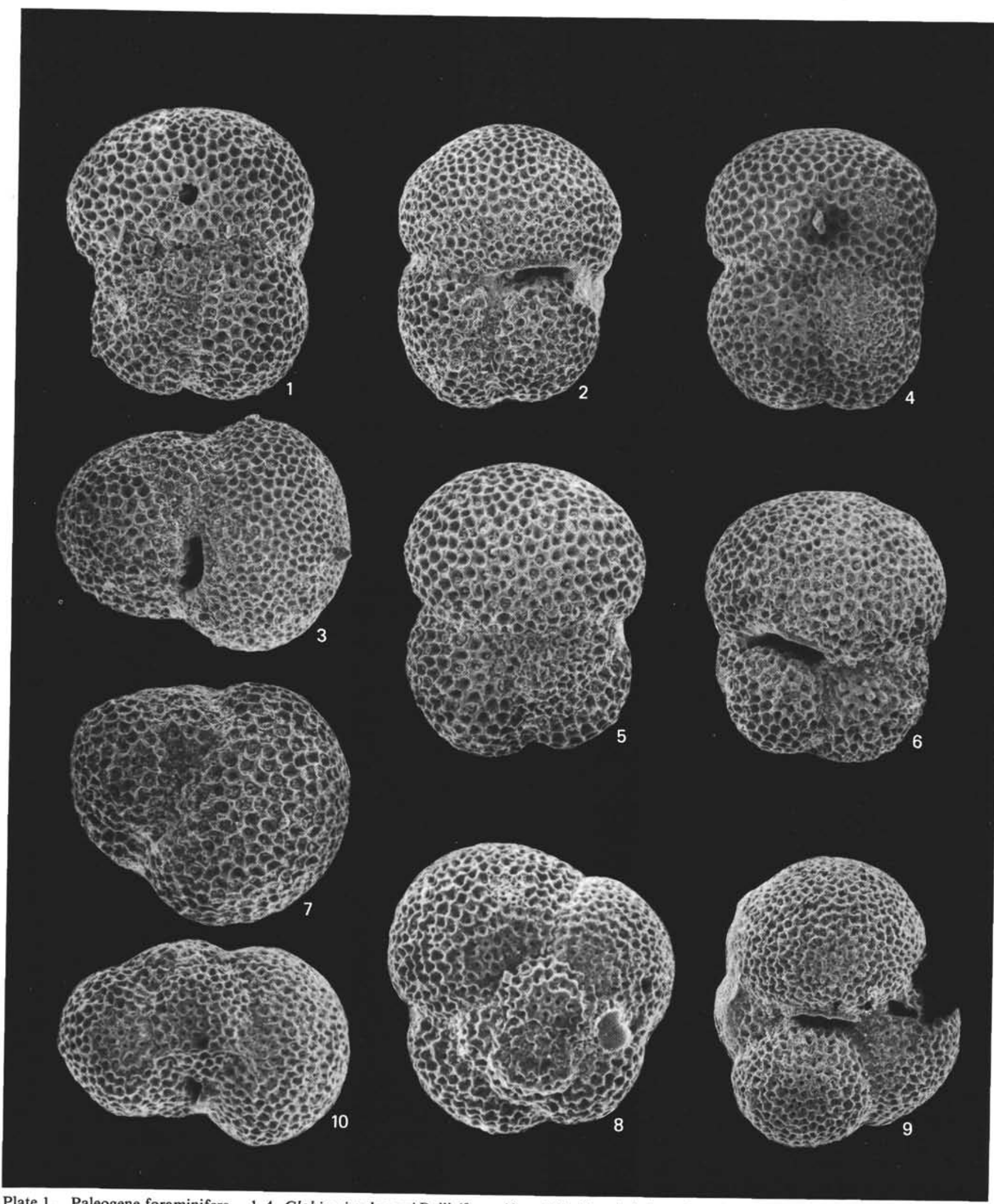

Plate 1. Paleogene foraminifers. 1-4. Globigerina boweri Bolli (form A), $\times 150$, (1) spiral view, Sample 512-19-1, 18-20 cm (2-4) Sample 51218-3, 50-52 cm (2, umbilical view; 3 , peripheral view; 4, spiral view). 5-7. Globigerina boweri Bolli (form B), Sample 512-18-3, 50-52 cm (5) $\times 170$, spiral view, $(6) \times 170$, umbilical view, (7) $\times 180$, peripheral view. $8-10$. Globigerina angiporoides minima Jenkins, Sample $512-19-1$,
$18-20 \mathrm{~cm},(8) \times 200$, spiral view, $(9) \times 150$, umbilical view, $(10) \times 170$, peripheral view. 

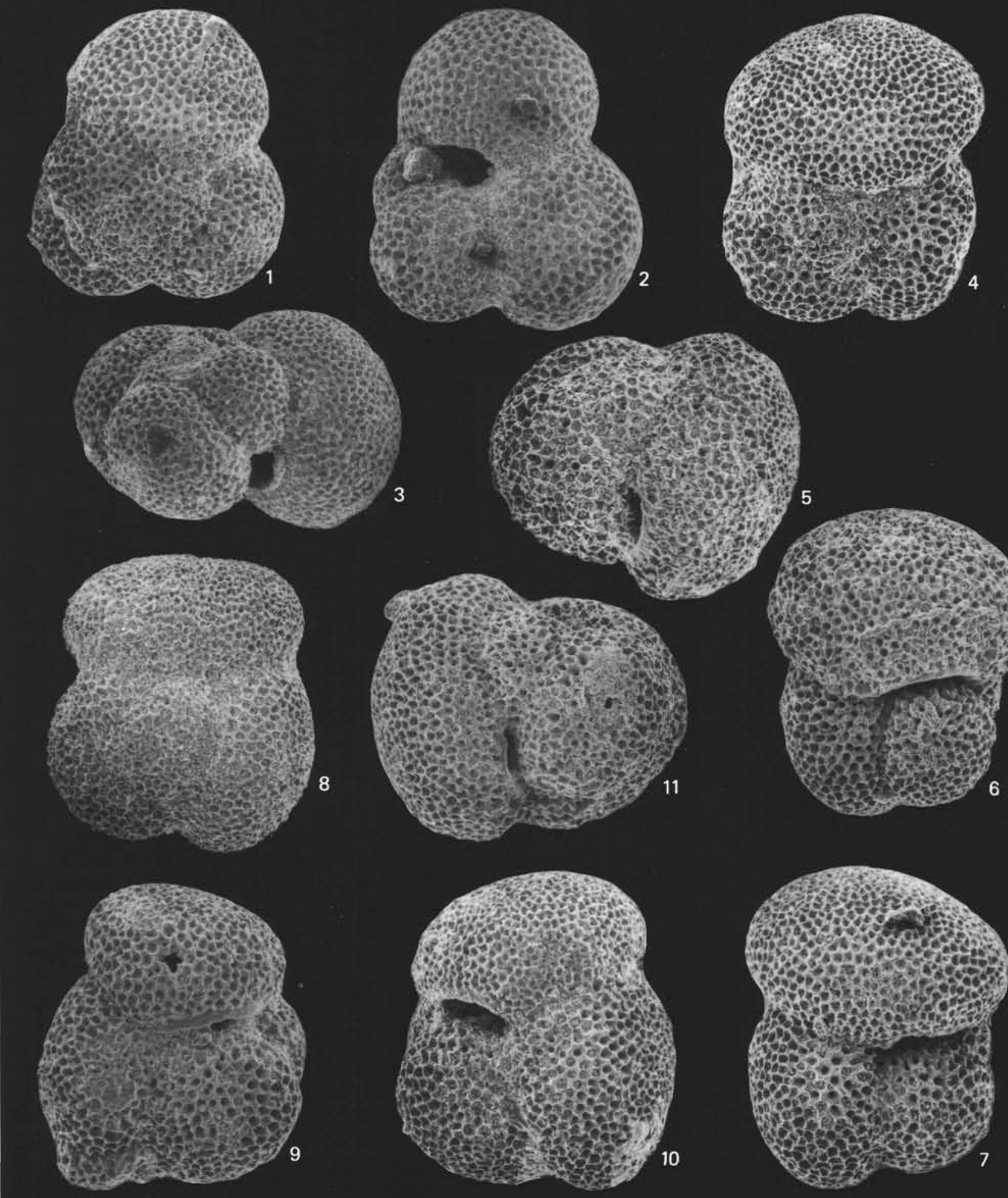

Plate 2. Paleogene foraminifers. 1-3. Globigerina pseudoeocaena Subbotina, Sample 512-14-2, 80-82 cm, (1-2) $\times 120$ (1, spiral view; 2 , umbilical view), (3) $\times 150$, peripheral view. 4-7. Globigerina frontosa Subbotina, $\times 120$, Sample 512-12-3, 12-14 cm, (4) spiral view, (5) peripheral view, (6-7) umbilical view. 8-11. Globigerina linaperta Finlay, Sample 512-13-3, 12-14 cm, (8) $\times 130$, spiral view, $(9-10) \times 150$, umbilical view, (11) $\times 130$, peripheral view. 


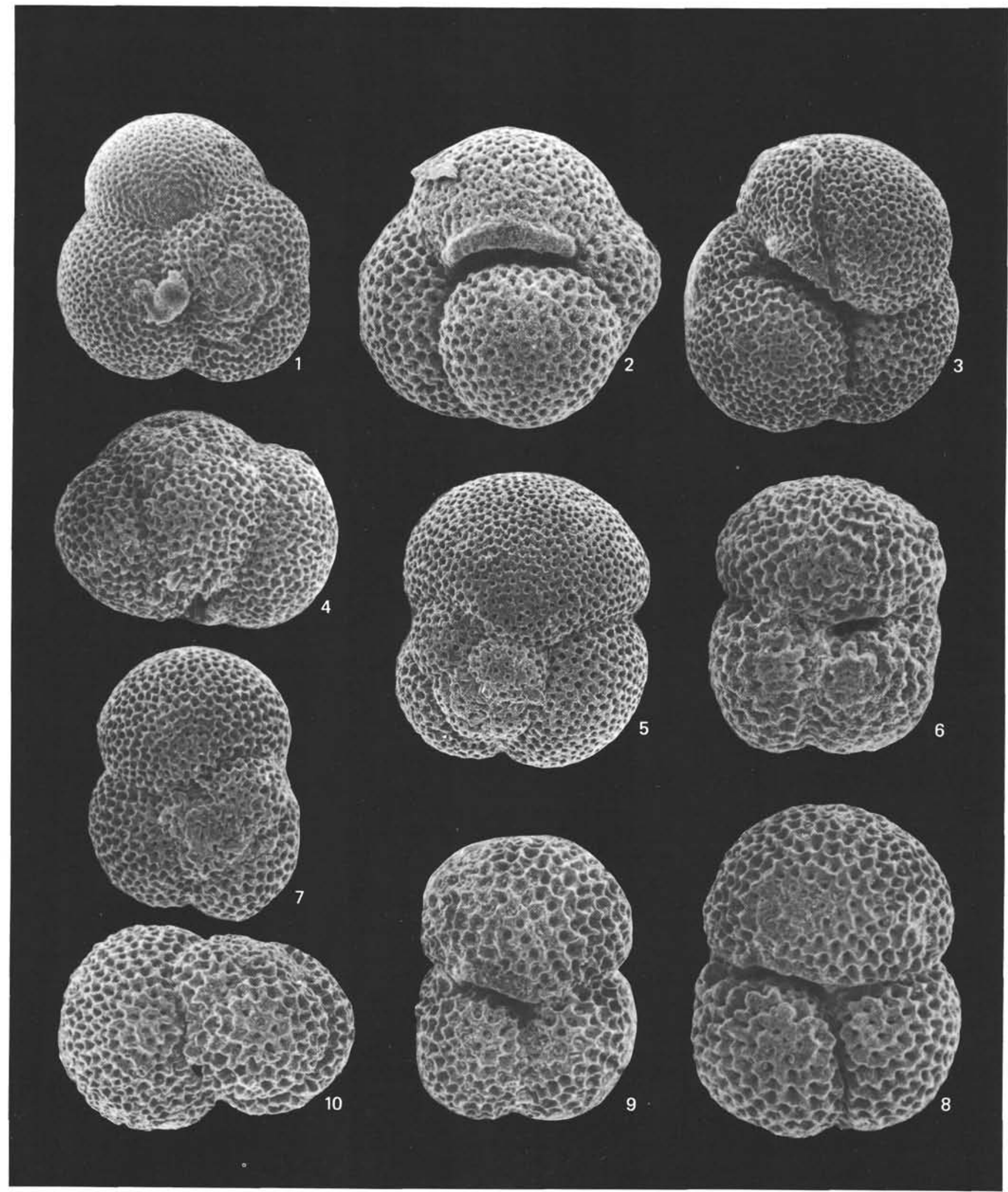

Plate 3. Paleogene foraminifers. 1-4. Globigerina angiporoides angiporoides Hornibrook, (1-3) Sample 512-12,CC (1, $\times 100$, spiral view; 2 , $\times 180$, umbilical view; $3, \times 120$, umbilical view), (4) $\times 150$, peripheral view, Sample 512-9,CC. 5-6. Globigerina tripartita Koch, Sample 511$20, \mathrm{CC},(5) \times 130$, spiral view, (6) $\times 170$, umbilical view. 7-10. Globigerina aff. linaperta Finlay, Sample 511-20,CC, (7) $\times 150$, umbilical view, $(8) \times 180$, umbilical view, $(9-10) \times 150(9$, umbilical view; 10 , peripheral view). 


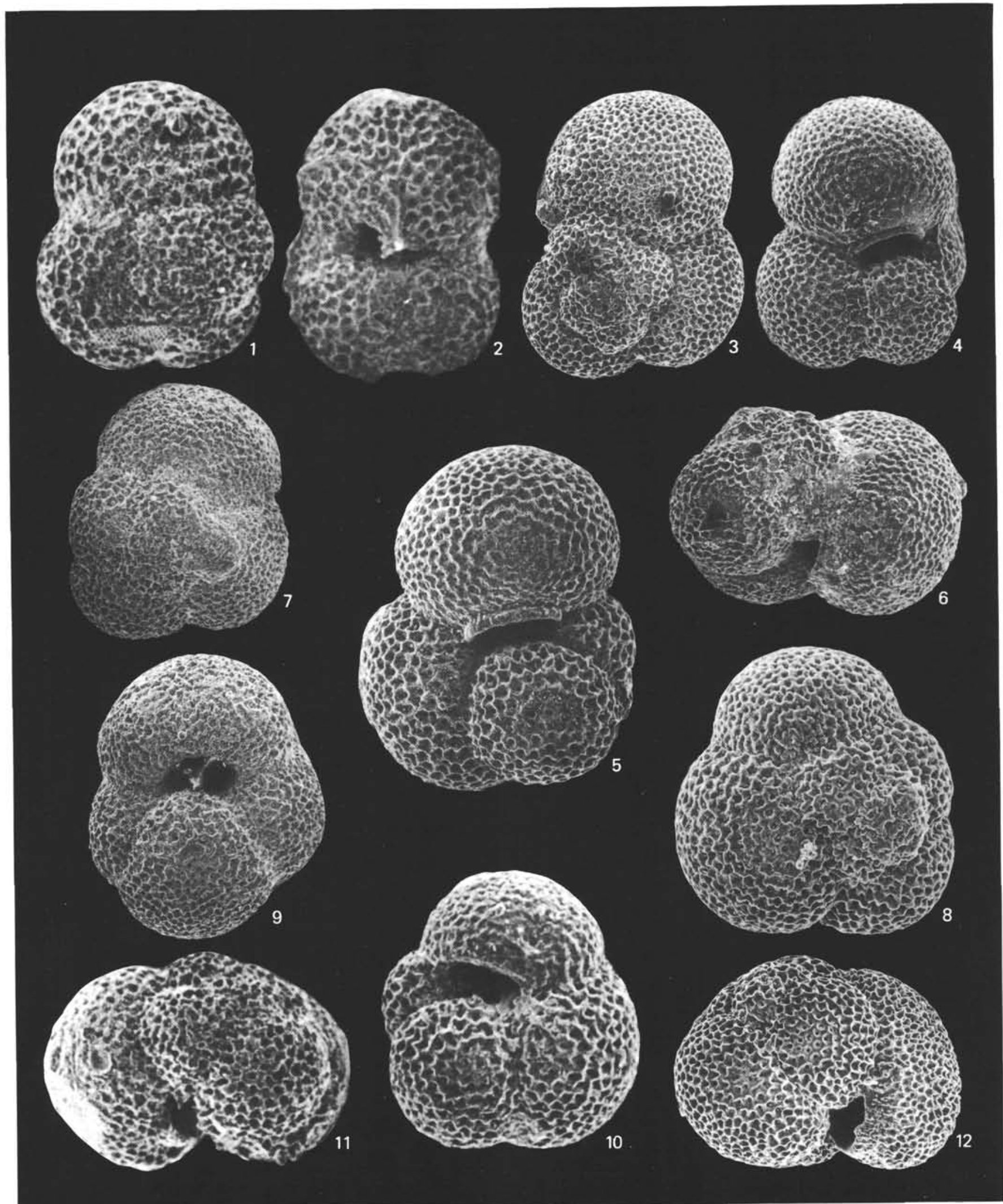

Plate 4. Paleogene foraminifers. 1-2. Globigerina galavisi Bermudez, Sample 513A-32,CC, (1) $\times 150$, spiral view, (2) $\times 130$, umbilical view. 3-6. Globigerina praebulloides Blow, Sample 511-12,CC, (3) $\times 120$, spiral view, (4-5) umbilical view $(4, \times 200 ; 5, \times 140),(6) \times 180$, veripheral view. 7-12. Globigerina prasaepis Blow, (7-8) spiral view $(7 \times 100$, Sample 511-9-1, 116-118 cm; $8 \times 180$, Sample 511-15-1, 20-22 $\mathrm{cm}),(9-12)$ Sample 513A-32-1, 110-112 $\mathrm{cm} \mathrm{9,} \times 110$, umbilical view; 10, $\times 200$, umbilical view; 11-12, $\times 150$, peripheral view). 

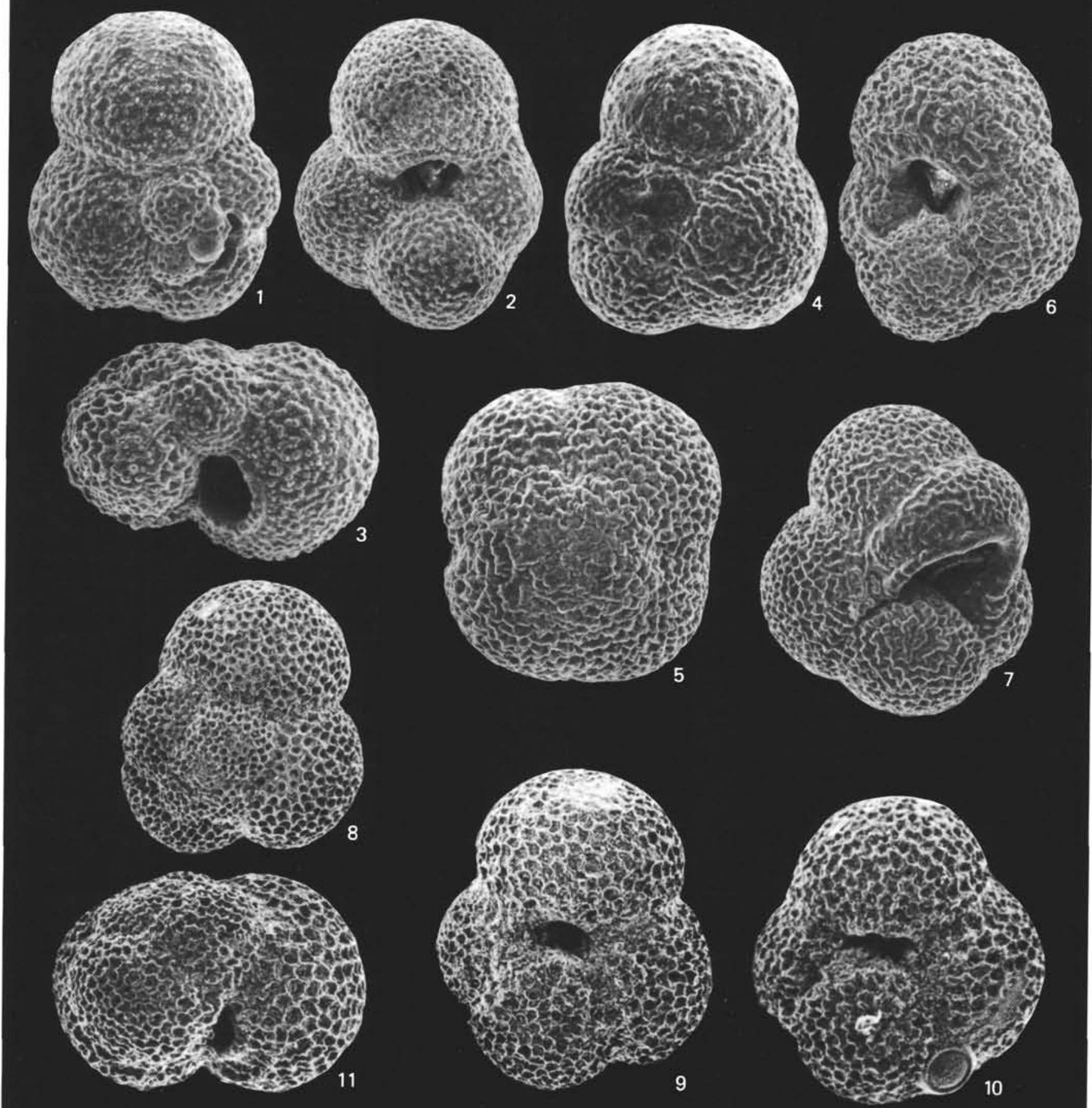

Plate 5. Paleogene foraminifers. 1-3. Globigerina officinalis Subbotina, $\times 200$, Sample $511-15-1,20-22 \mathrm{~cm}$ (1) spiral view, (2) umbilical view,

(3) peripheral view. 4-7. Globigerina labiacrassata Jenkins (4-6) Sample 511-17-1,90-92 cm (4, $\times 150$, spiral view; 5, $\times 200$, spiral view; 6, $\times 150$, umbilical view), (7) $\times 150$, umbilical view, Sample 511-13,CC. 8-11. Globigerina senilis Bandy, Sample 513A-32-1, 110-112 cm, (8) $\times 100$, spiral view, $(9-10)$ umbilical view $(9, \times 120 ; 10, \times 150),(11) \times 120$, peripheral view. 

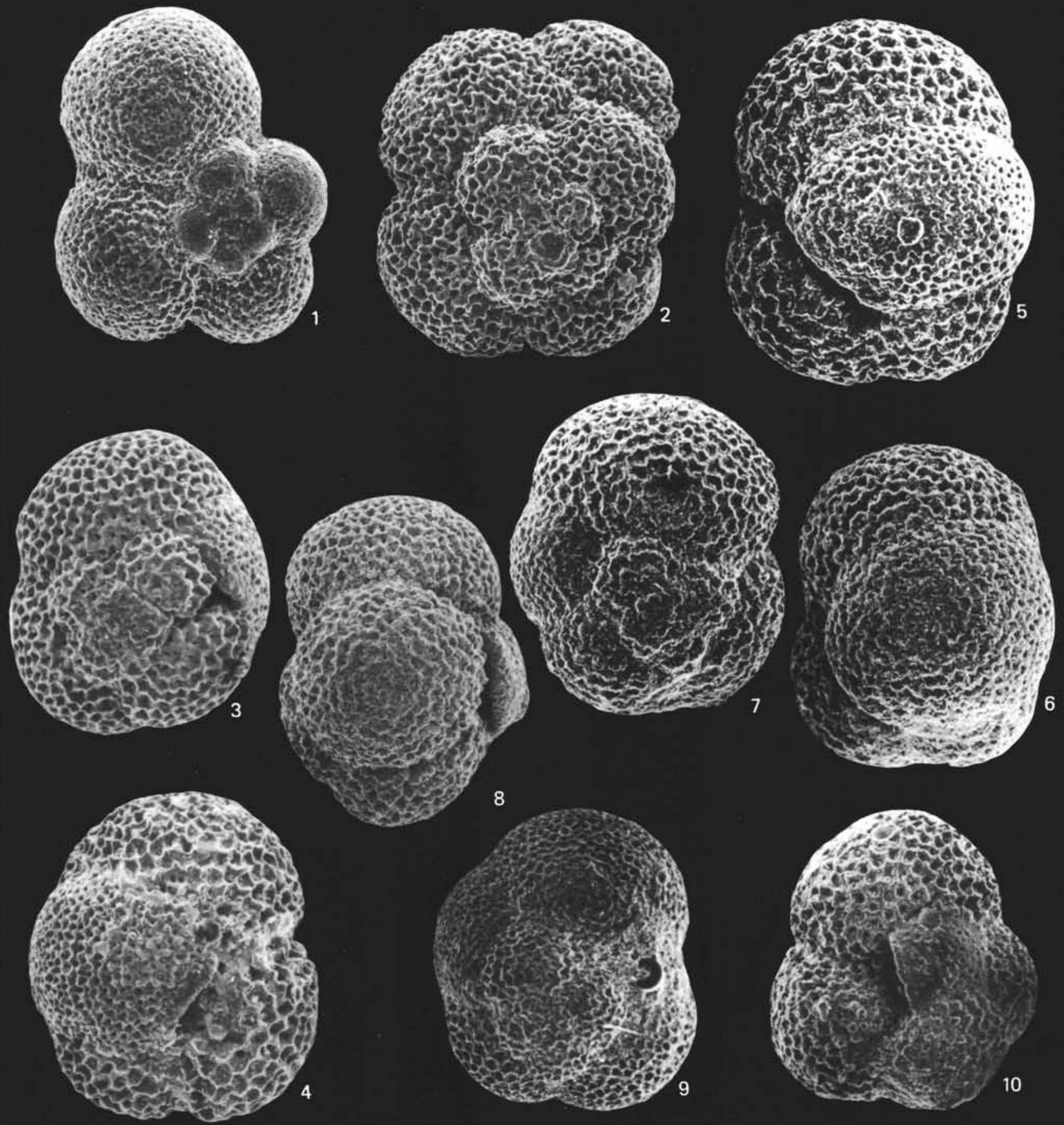

Plate 6. Paleogene foraminifers, 1-2. Globigerina ouachitaensis Howe and Wallace, $\times 220$, spiral view, Sample 511-11,CC. 3-4. Globigerinita pera (Todd), Sample 511-20,CC, (3) $\times 160$, spiral view, (4) $\times 180$, umbilical view. 5-8. Globigerinita martini Blow and Banner, Sample 513A$32-2,110-112 \mathrm{~cm},(5-6)$ umbilical view $(5, \times 500 ; 6, \times 180),(7) \times 150$, spiral view, $(8) 160$, peripheral view. 9-10. Globigerinita unicava Bolli, Loeblich, and Tappan, Sample $513 \mathrm{~A}-32-1,110-112 \mathrm{~cm},(9) \times 150$, umbilical view, (10) $\times 130$, spiral view. 

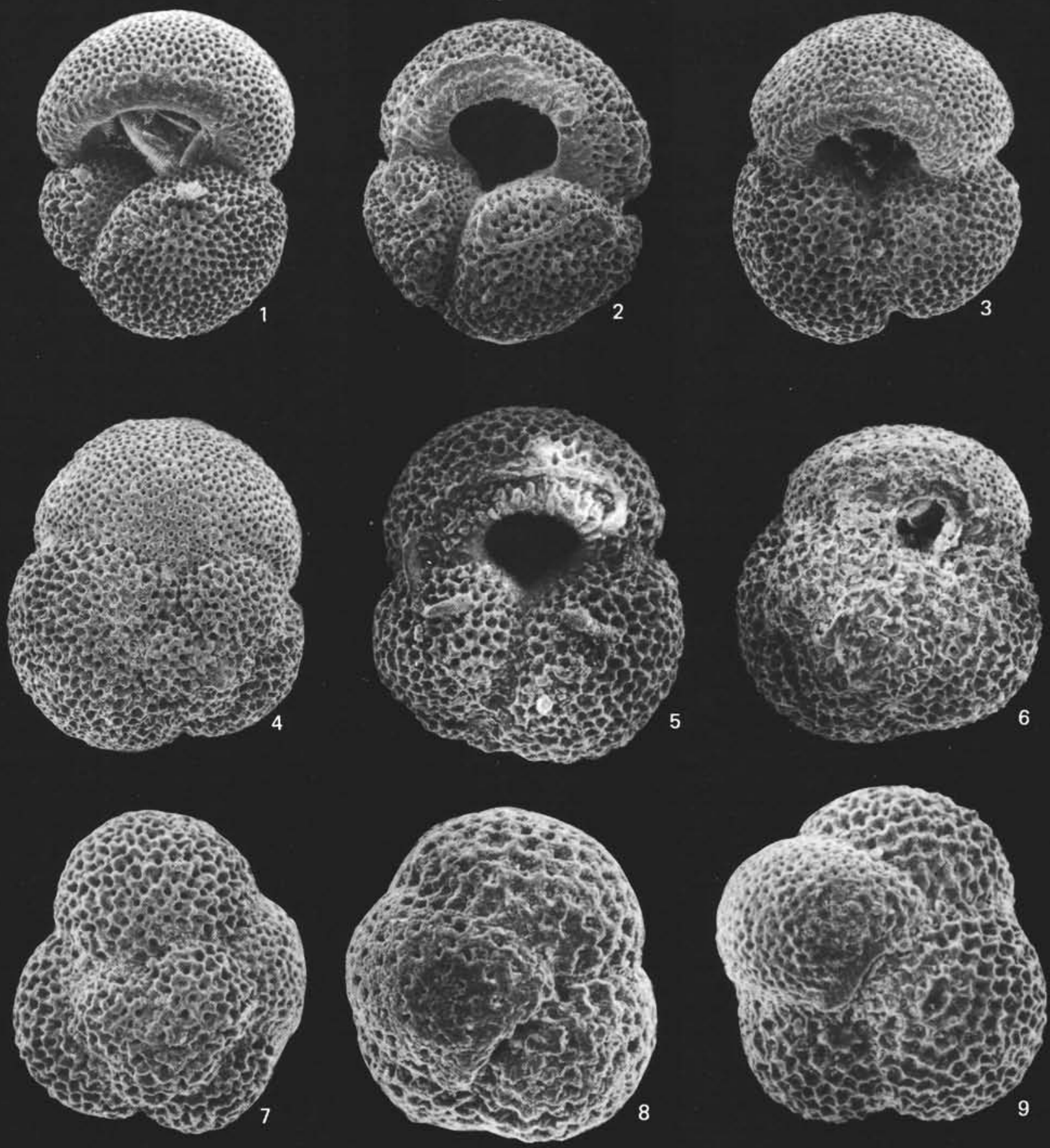

Plate 7. Paleogene foraminifers. 1-5. Globigerapsis index (Finlay), (1-3) umbilical view, Sample 512-18-3, 20-22 cm (1-2, × 120; 3, $\times 150),(4-5)$

Sample 511-18,CC $(4, \times 120$, spiral view; 5, $\times 150$, umbilical view). 6. Globigerapsis aff. tropicalis Blow and Banner, $\times 170$, spiral view, Sample 511-18,CC. 7-9. Globorotaloides turgidus (Finlay), Sample 512-13-3, 12-14 cm, (7) $\times 150$, spiral view, (8) $\times 270$, umbilical view, $(9) \times 250$, umbilical view. 

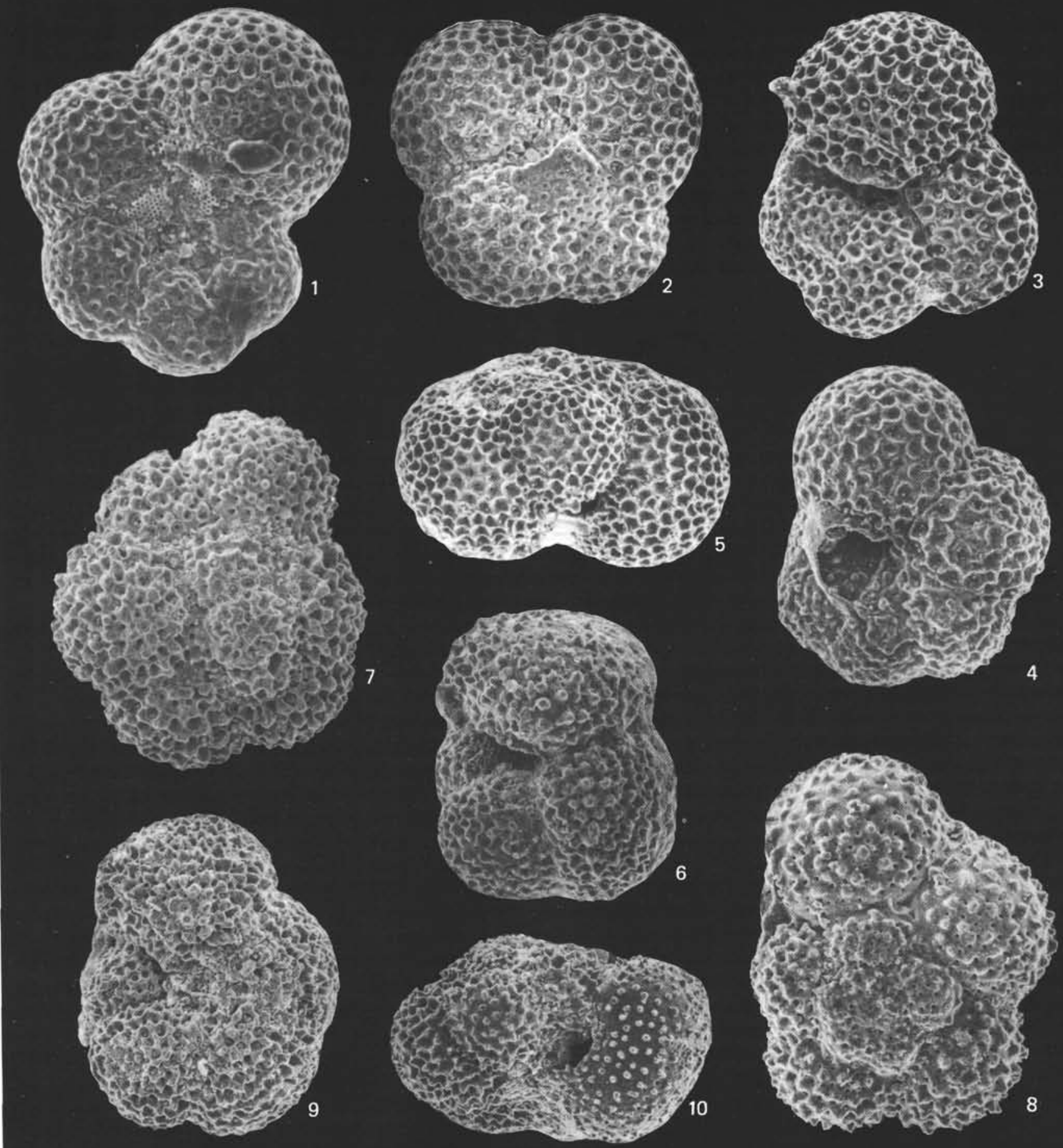

Plate 8. Paleogene foraminifers. 1-5. Globorotaloides suteri Bolli (1) $\times 240$, spiral view, Sample 511-20,CC, (2-3) umbilical view, Sample 511$18, \mathrm{CC}(2, \times 220 ; 3, \times 200),(4-5)$ Sample 511-20,CC (4, $\times 250$, umbilical view; 5, $\times 200$, peripheral view). 6. Acarinina pseudotopilensis Subbotina, $\times 230$, umbilical view, Sample 512-19-1, 10-20 cm. 7-10. Acarinina sp., Sample 512-11,CC, (7-8) spiral view (7, $\times 240 ; 8, \times 260),(9)$ $\times 200$, umbilical view, $(10) \times 260$, spiral view. 

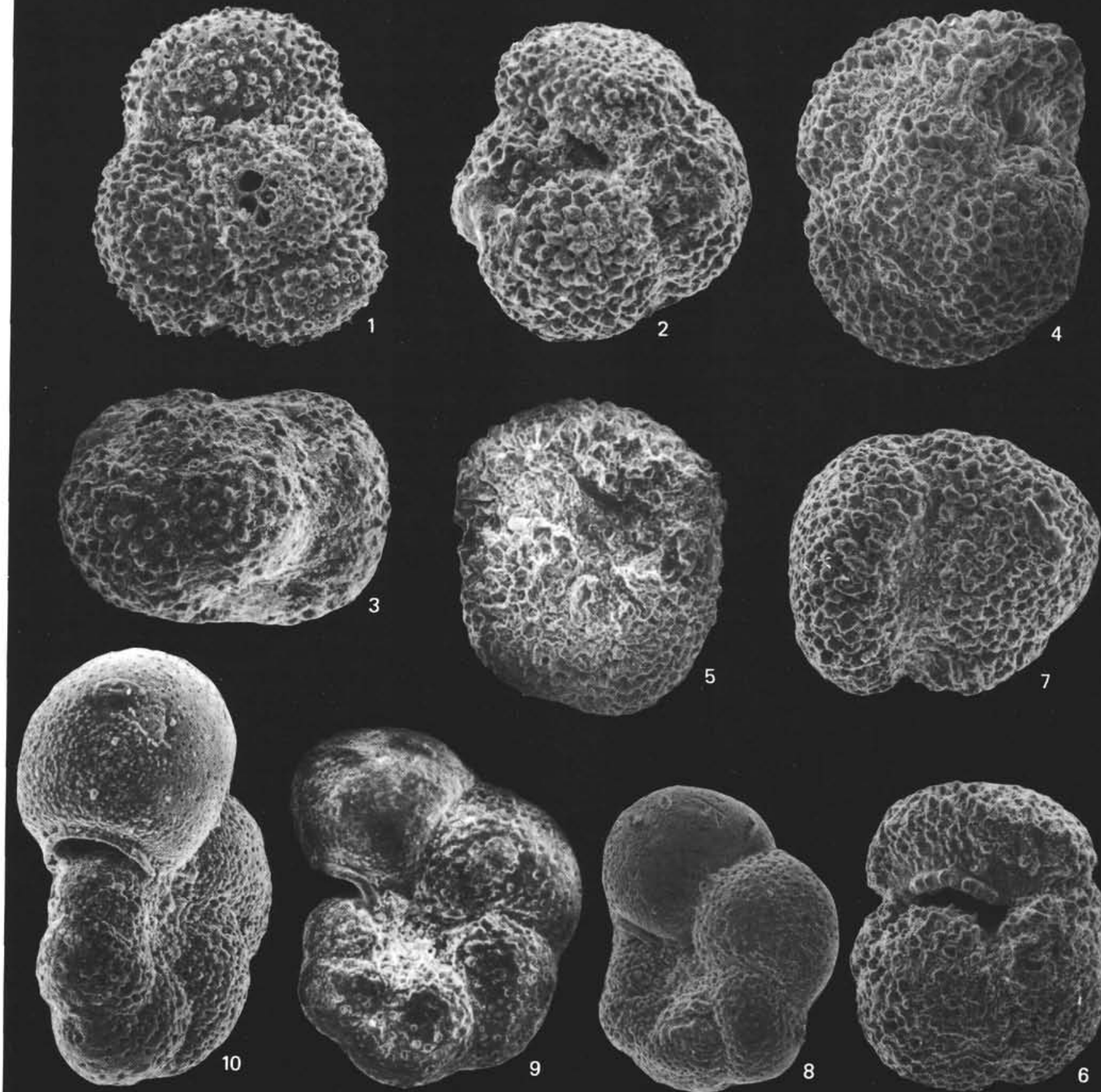

Plate 9. Paleogene foraminifers. 1-3. Acarinina bullbrooki (Bolli), $\times 200$, Sample 512-19-1, 18-20 cm, (1) spiral view, (2) umbilical view, (3) peripheral view. 4-7. Pseudogloboquadrina primitiva (Finlay), Sample 512-18-3, 50-52 cm, (4) $\times 180$, spiral view, $(5-7) \times 150(5-6$, umbilical view; 7, peripheral view). 8-10. Pseudohastigerina micra (Cole), Sample 512-19-1, 18-20 cm, (8-9) side view $(8, \times 170 ; 9, \times 250),(10) \times 230$, apertural view. 

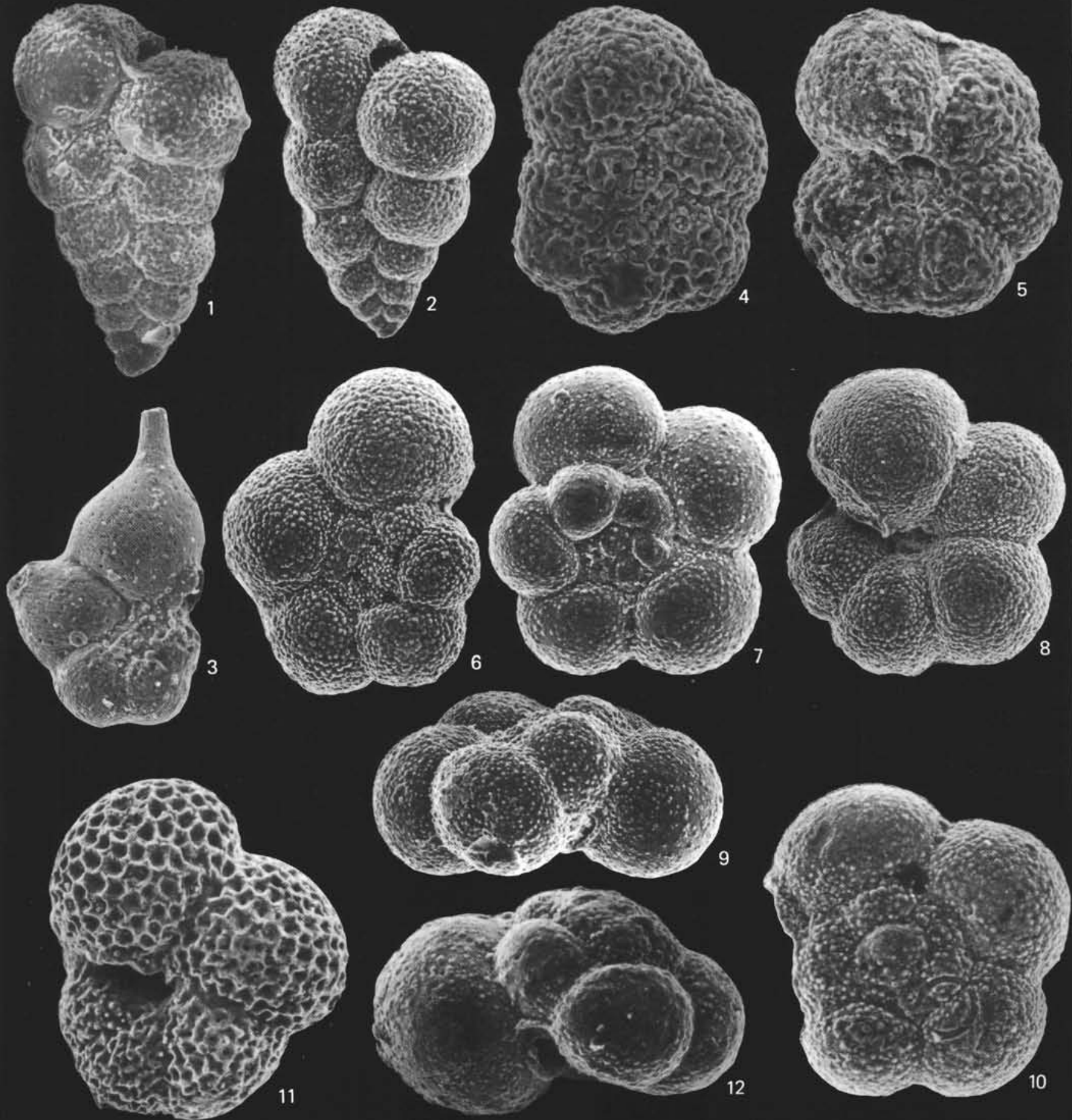

Plate 10. Paleogene foraminifers. 1-2. Chiloguembeliina cubensis $($ Palmer), side view, Sample 511-18,CC, (1) $\times 300,(2) \times 200$. 3. Hantkenina sp., $\times 300$, side view, Sample 512-18,CC. 4-5. Globorotalia collactea Finlay, $\times 350$, Sample 512-19-1, 18-20 cm, (4) spiral view, (5) umbilical view. 6-9. Globorotalia gemma Jenkins, Sample 511-11,CC, 6-7) $\times 250$, spiral view, $(8) \times 250$, umbilical view, (9) $\times 300$, peripheral view. 10-12. Globorotalia munda Jenkins, $\times 300$, Sample 511-20,CC, (10) spiral view, (11) umbilical view, (12) peripheral view. 

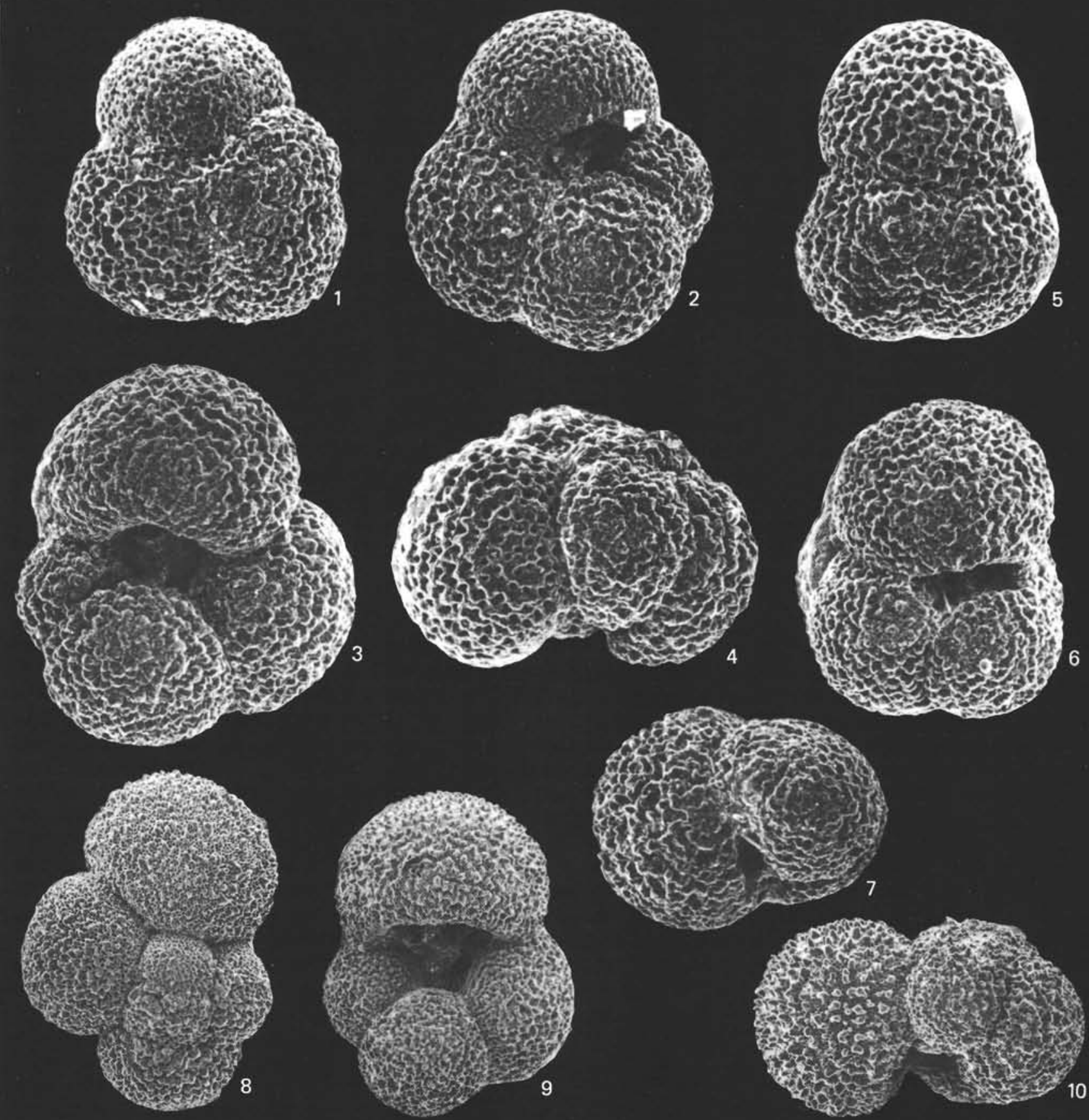

Plate 11. Neogene-Quaternary foraminifers. 1-4. Globigerina woodi woodi Jenkins, Sample 513A-15,CC, (1) $\times 170$, spiral view, (2-3) umbilical view $(2, \times 180 ; 3, \times 200),(4) \times 200$, peripheral view. 5-7. Globigerina woodi connecta Jenkins, Sample 513A-15, CC, (5) $\times 180$, spiral view, $(6)$ $\times 170$, umbilical view, (7) $\times 160$, peripheral view. $8-10$. Globigerina bulloides bulloides d'Orbigny Sample 511-1, top, (8) $\times 90$, spiral view, (9) $\times 100$, umbilical view, $(10) \times 120$, peripheral view. 


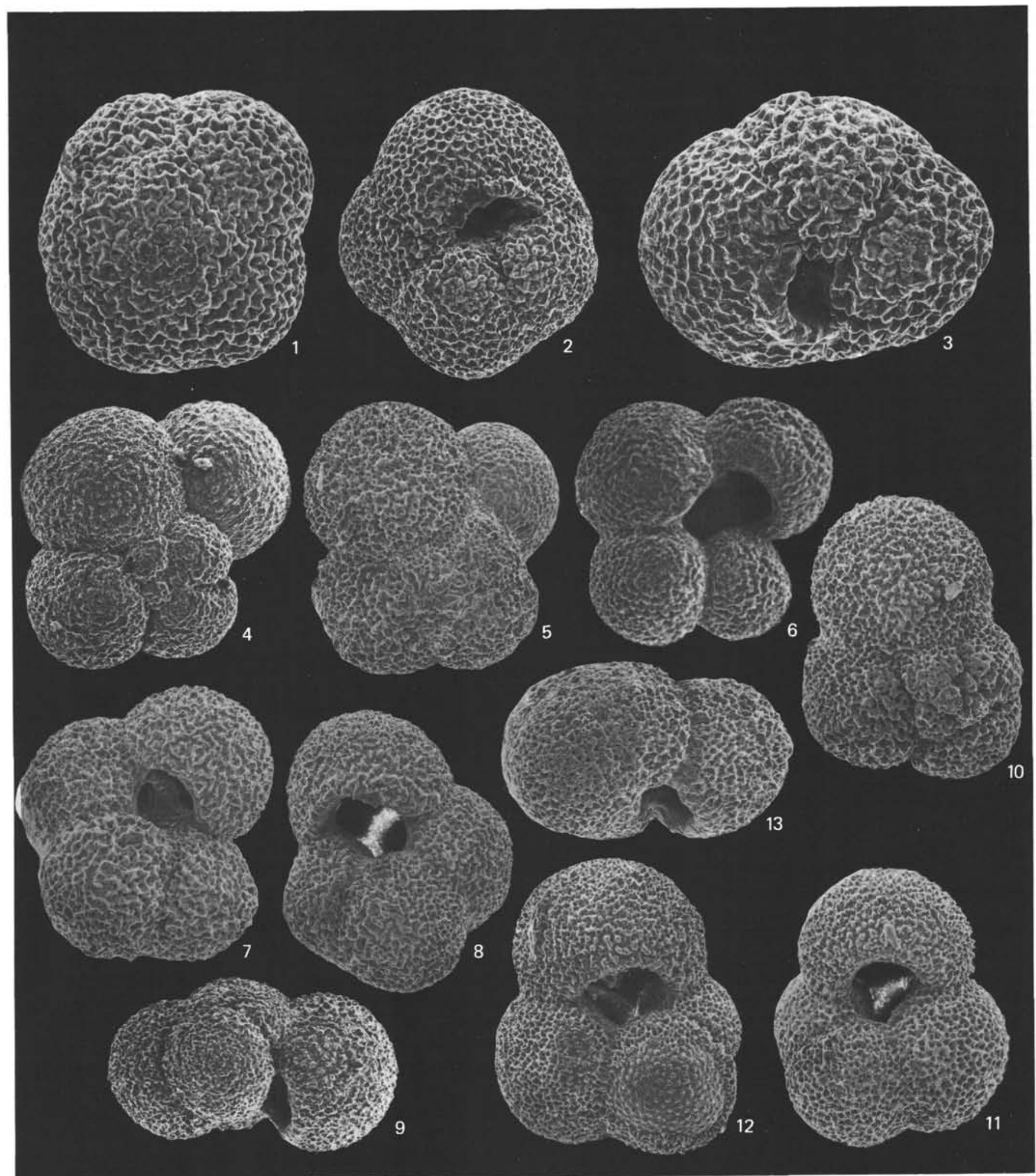

Plate 12. Neogene-Quaternary foraminifers. 1-3. Globigerina pachyderma (Ehrenberg), Sample 511-1, top, (1) $\times 200$, spiral view, (2) $\times 160$, umbilical view, (3) $\times 200$, peripheral view. 4-9. Globigerina bulloides quadrilatera Galloway and Wissler, (4-6) Sample 512-5,CC (4, $\times 100$, spiral view; $5, \times 120$, spiral view; $6, \times 120$, umbilical view) $(7-8)$ Sample $511-1$, top $(7, \times 150$, umbilical view; $8, \times 120$, umbilical view), (9) $\times 100$, peripheral view, Sample 512-5,CC. 10-13. Globigerina bulloides decoraperta Takayanagi and Saito, Sample $512-5, \mathrm{CC},(10) \times 120$, spiral view, (11-12) $\times 120$, umbilical view, (13) $\times 150$, peripheral view. 


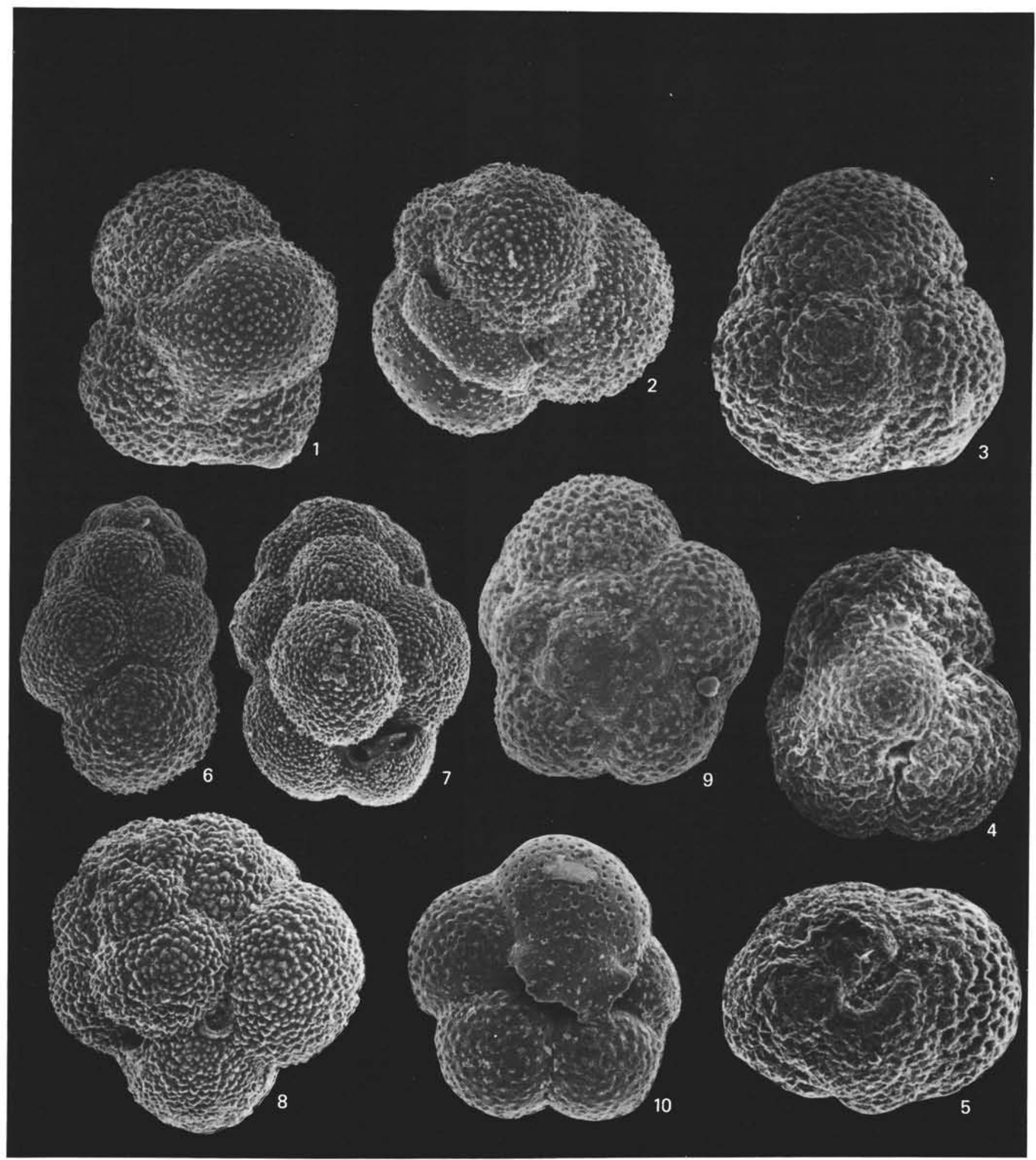

Plate 13. Neogene-Quaternary foraminifers. 1-2. Globigerinita glutinata (Egger), $\times 270$, Sample 511-1, top, (1) umbilical view, (2) peripheral view. 3-5. Globigerinita dissimilis (Cushman and Bermudez), $\times 150$, Sample 513A-15,CC, (3) spiral view, (4) umbilical view, (5) peripheral view. 6-8. Globigerinita uvula (Ehrenberg), peripheral view, Sample 511-1, top, $(6) \times 270,(7) \times 150,(8) \times 160$. 9-10. Turborotalita aff. iota Parker, $\times 250$, Sample 511-1, top, (9) umbilical view, (10) spiral view. 


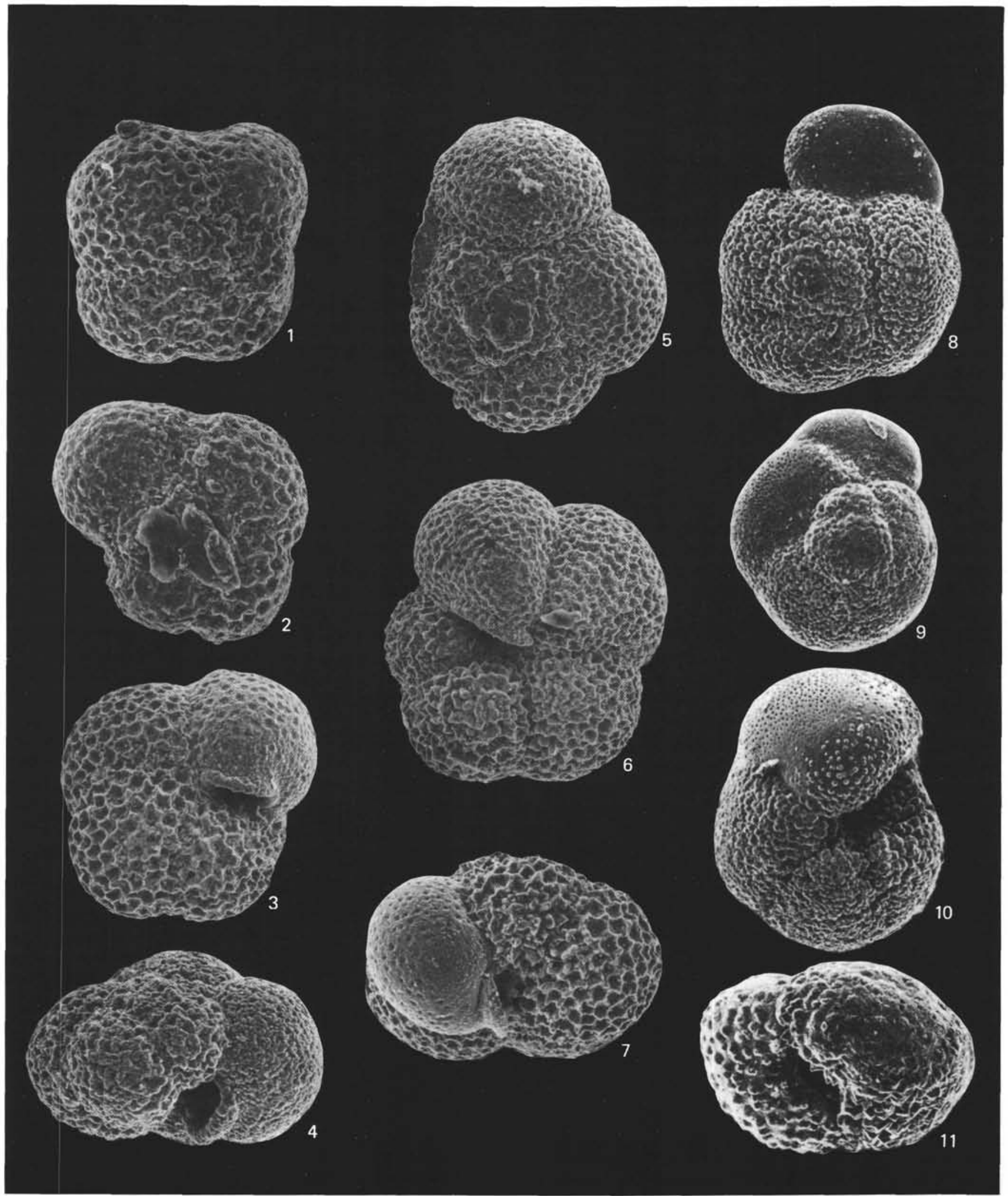

Plate 14. Neogene-Quaternary foraminifers. 1-4. Globorotalia continuosa Blow, Sample 512-5,CC, (1-2) $\times 250$, spiral view, (3) $\times 200$, umbilical view, (4) $\times 250$, peripheral view. 5-7. Globorotalia acostaensis Blow, $\times 200$, Sample 512-1,CC, (5-6) spiral view, (7) peripheral view. 8-11. Globorotalia puncticulata (Deshayes), Sample 513-3-2, 38-40 cm (8-9) $\times 100$, spiral view, $(10) \times 120$, umbilical view, (11) $\times 100$, peripheral view. 


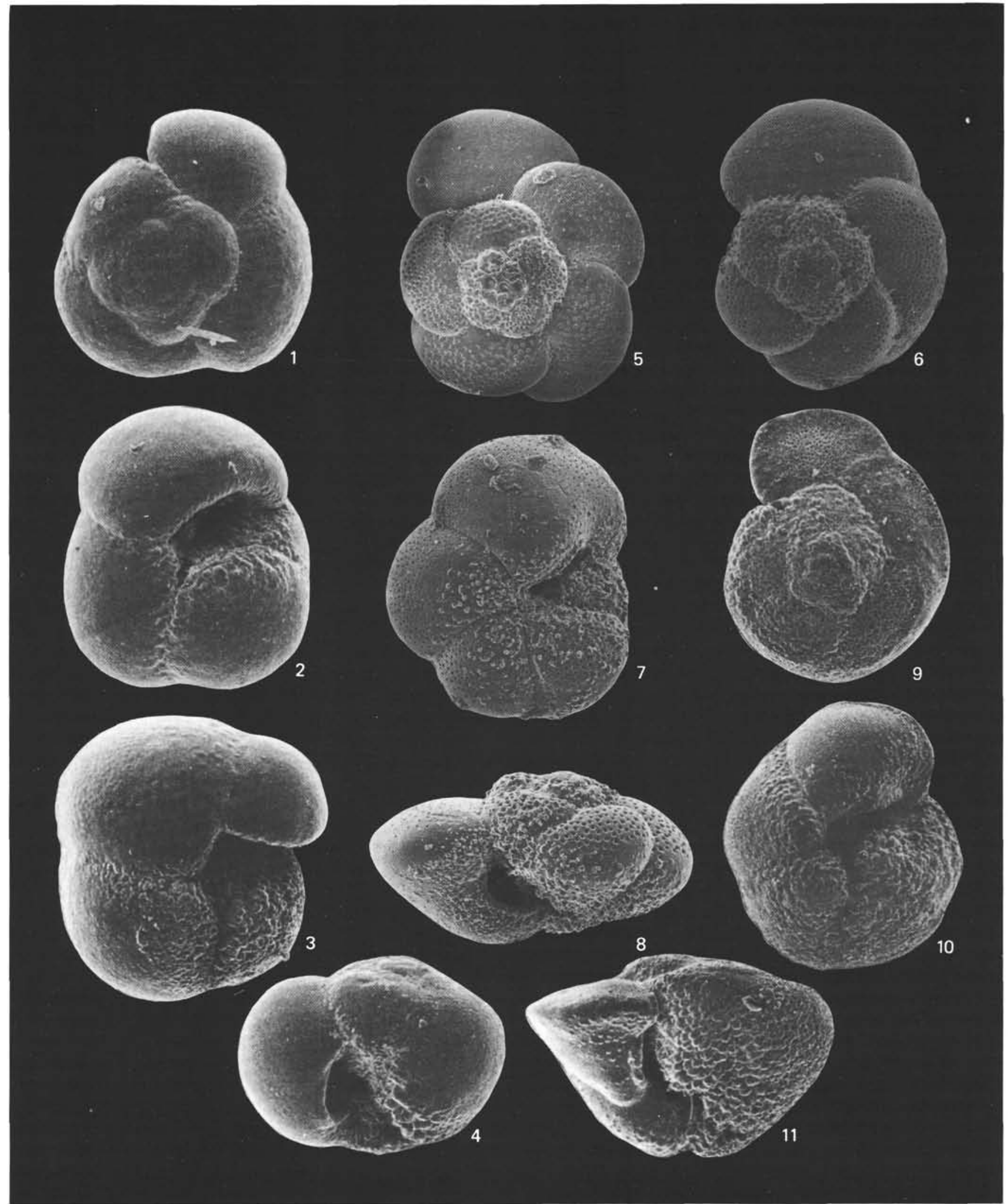

Plate 15. Neogene-Quaternary foraminifers. 1-4. Globorotalia inflata (d’Orbigny), $\times 100$, Sample 511-1, top, (1) spiral view, (2-3) umbilical view, (4) peripheral view. 5-8. Globorotalia scitula (Brady), Sample 512-5,CC, $(5-6) \times 100$, spiral view, (7) $\times 120$, umbilical view, $(8) \times 160$, peripheral view. 9-11. Globorotalia truncatulinoides (d'Orbigny), Sample 511-1, top, $(9-10) \times 90$ (9, spiral view; 10, umbilical view), (11) $\times 100$, peripheral view. 